\title{
Biochar physicochemical properties: pyrolysis temperature and feedstock kind effects
}

\author{
Agnieszka Tomczyk (D) Z Zofia Sokołowska • Patrycja Boguta
}

Published online: 5 February 2020

(C) The Author(s) 2020

\begin{abstract}
Biochar is a pyrogenous, organic material synthesized through pyrolysis of different biomass (plant or animal waste). The potential biochar applications include: (1) pollution remediation due to high CEC and specific surface area; (2) soil fertility improvement on the way of liming effect, enrichment in volatile matter and increase of pore volume, (3) carbon sequestration due to carbon and ash content, etc. Biochar properties are affected by several technological parameters, mainly pyrolysis temperature and feedstock kind, which differentiation can lead to products with a wide range of values of $\mathrm{pH}$, specific surface area, pore volume, CEC, volatile matter, ash and carbon content. High pyrolysis temperature promotes the production of biochar with a strongly developed specific surface area, high porosity, $\mathrm{pH}$ as well as content of ash and carbon, but with low values of CEC and content of volatile matter. This is most likely due to significant degree of organic matter decomposition. Biochars produced from animal litter and solid waste feedstocks exhibit lower surface areas, carbon content, volatile matter and high CEC compared to biochars produced from crop residue and wood biomass, even at higher pyrolysis temperatures. The reason for this difference is considerable variation in lignin and cellulose content as well as in moisture
\end{abstract}

A. Tomczyk $(\bowtie) \cdot$ Z. Sokołowska $\cdot$ P. Boguta Institute of Agrophysics, Polish Academy of Sciences, Doświadczalna 4, 20-290 Lublin, Poland

e-mail: atomczyk@ipan.lublin.pl content of biomass. The physicochemical properties of biochar determine application of this biomaterial as an additive to improve soil quality. This review succinctly presents the impact of pyrolysis temperature and the type of biomass on the physicochemical characteristics of biochar and its impact on soil fertility.

Keywords Biochar - Feedstock kind · Soil quality · Physicochemical properties - Pyrolysis temperature

\section{Introduction}

Biochar is a carbon-rich material. It can be used not only as a renewable fuel, but also as an additive for improvement of soil quality (Lehmann and Joseph 2009). The nature of carbon structures is the key reason for the high stability (Lehmann et al. 2011; Nguyen et al. 2010). The most pronounced chemical difference between biochar and other organic matter is much higher proportion of aromatic $\mathrm{C}$ and condensed aromatic structures, in contrast to other aromatic structures of soil organic matter, such as lignin (Schmidt and Noack 2000). The condensed aromatic structure of biochars can have varying forms, including amorphous $\mathrm{C}$ (which dominates at lower pyrolysis temperatures), turbostratic $\mathrm{C}$ (formed at higher temperatures) and graphite C (Keiluweit et al. 2010; 
Nguyen et al. 2010). Biochar exhibits high biodegradability, high contents of total and organic carbon, as well as optimal concentrations of micro- and macroelements (potassium, sodium, magnesium, calcium, copper, zinc, iron etc.) (Malińska 2012). It is generally characterized by a high specific surface area, high content of surface functional groups, $\mathrm{pH}$ and porosity (Hernandez-Mena et al. 2014; Lehmann et al. 2011). Hernandez-Mena et al. (2014) showed that biochar exhibits high porosity, with longitudinal pores of sizes ranging from micro- to macropores. Large pores, originating from the vascular bundles of the raw biomass, are important for improving soil quality because they can provide habitats for symbiotic microorganisms (Thies and Rillig 2009). Porous structures can also act as release routes for pyrolytic vapours (Lee et al. 2013a).

Biochar is created through the pyrolysis of biomass. Pyrolysis represents the oldest known method of biomass thermal processing. The use of pyrolysis dates back at least to ancient Egypt (Mohan et al. 2006). Biowastes from agriculture, the food industry, and forestry are the main sources of feedstock (Shakya and Agarwal 2017). The most popular substrates include wood chips and pellets, tree cuttings, bagasse, distiller grains, press cakes from the oil and juice industry, rice husks and crop residues (Parmar et al. 2014). However, production can also be based on biomass sources other than lignocelluloses matter, such as sewage sludge, poultry litter, excrement, bones, dairy manure etc. (Kumar et al. 2016). The selection of suitable conditions for producing a char with the desired properties therefore requires knowledge of dependencies and influencing factors, both quantitatively and qualitatively (Weber and Quicker 2018; Zhang et al. 2019). The products of pyrolysis are an oil (a mixture of hydrocarbons), synthetic gas (mixed hydrocarbon gases) and biochar (Lewandowski et al. 2010; Verheijen et al. 2010). The proportions of these individual products depend on the temperature range, pressure, residence time, etc. (Brewer 2012; Cheah et al. 2016; Lewandowski et al. 2010). It is summarized in Table 1. The slow pyrolysis is the most effective for biochar production with a typical biochar yield of $35.0 \%$ from dry biomass weight. The fast pyrolysis is the most efficient method for producing biofuels and the gasification is the most efficient for producing syngas and hence is usually used to generate heat and energy (Cheah et al.
2016). As a result of high heating rates and short residence times, fast pyrolysis tends to yield higher proportions of oils. In contrast, slow pyrolysis tends to yield higher proportions of biochars because of slow heating rates and longer residence times (Daful and Chandraratne 2018). Furthermore, the pyrolysis of biomass may contribute to the formation of phytotoxic and potentially carcinogenic compounds under some conditions (type of feedstock, pollution in feedstock, and pyrolysis parameters) (Ndriangu et al. 2019). Some of the heavy metals are transformed into less toxic forms, pathogens are eliminated as the result of the pyrolysis process (Paz-Ferreiro et al. 2018), but nitrogen and sulphur are lost during pyrolysis (Maguire and Agblevor 2010). Therefore, biochar has been researched as a soil modifier.

Biochar has a long history as a soil modifier (Brewer 2012). Early Japanese farmers used unique manure called "haigoe", which was prepared by adding human waste to rice husk biochar and applying it to fields some time before planting crops (Shakya and Agarwal 2017). Moreover, the addition of biochar may affect the biological community composition of soil, as demonstrated for the 'Terra Preta' soils in the Amazon (Lehmann et al. 2011). Soil is a complex material and comprises minerals, soil organic matter, water, and air. These fractions greatly influence soil texture, structure, and porosity (Baghdadi and Zribi 2016). These properties subsequently affect air and water movement in the soil layers and thus the soil's ability to function (Naga Raju et al. 2017). Therefore, soil physicochemical properties have a great influence on the soil quality. Biochar generally increases carbon sequestration in soil (Sohi et al. 2010), reduces the emission of ammonia and carbon dioxide (Cabeza et al. 2018), lowers soil compactness, optimizes compost (Liang et al. 2010), improves water retention and the sorption of heavy metals, increases the availability of micronutrients for plants and increases the pH of soils (Van Zwieten et al. 2010). Biochar also stimulates the growth of rhizosphere microorganisms and mycorrhizal fungi (Głuszek et al. 2017). These bacteria and fungi may also promote plant growth (Compant et al. 2010).

The authors provided a more comprehensive and insightful scientific overview. The objective of this review presented herein is to assess: (1) the physicochemical characteristics of biochar formed at different temperatures and from different biomass, (2) the 
Table 1 Products of pyrolysis processes in a variety of conditions

\begin{tabular}{|c|c|c|c|c|c|c|}
\hline \multirow[t]{2}{*}{ Process } & \multirow[t]{2}{*}{$\begin{array}{l}\text { Pyrolysis temperature } \\
\left({ }^{\circ} \mathrm{C}\right)\end{array}$} & \multirow[t]{2}{*}{ Pressure } & \multirow[t]{2}{*}{$\begin{array}{l}\text { Residence } \\
\text { time }\end{array}$} & \multicolumn{3}{|c|}{$\begin{array}{l}\text { The proportion of products in } \\
\text { the pyrolysis process }(\%)\end{array}$} \\
\hline & & & & $\begin{array}{l}\text { Bio- } \\
\text { oil }\end{array}$ & $\begin{array}{l}\text { Synthetic } \\
\text { gas }\end{array}$ & Biochar \\
\hline Fast Pyrolysis & $400-600$ & $\begin{array}{l}\text { Vacuum- } \\
\text { atmospheric }\end{array}$ & Seconds & 75.0 & 13.0 & 12.0 \\
\hline $\begin{array}{l}\text { Biocarbonization (slow } \\
\text { pyrolysis) }\end{array}$ & $350-800$ & Atmoshperic & Seconds-hours & 30.0 & 35.0 & 35.0 \\
\hline Gasification & $700-1500$ & $\begin{array}{l}\text { Atmospheric- } \\
\text { elevated }\end{array}$ & $\begin{array}{l}\text { Second- } \\
\text { minutes }\end{array}$ & 5.0 & 85.0 & 10.0 \\
\hline
\end{tabular}

mechanisms of change in biochar structure, surface and main physicochemical properties, (3) discussion of biochars effect on the physicochemical properties of the soil and biological properties of the soil and (4) the application and potential effects of biochar as a soil adsorbent. The explanation of the main mechanisms of changes in physicochemical properties of biochar during pyrolysis at various temperatures and the types of feedstock is necessary to determine the ability of biochar to remediate various soils, which is useful in future studies.

\section{Effects of pyrolysis temperature}

Process of biochar production had three stages: prepyrolysis; main-pyrolysis and formation of carbonaceous soil products (Lee et al. 2017). The first stage (from ambient temperature to $200{ }^{\circ} \mathrm{C}$ ) is attributed to evaporation of moisture and light volatiles. The moisture evaporation causes breakage of bonds and formation hydroperoxide, $-\mathrm{COOH}$ and $-\mathrm{CO}$ groups (Cárdenas-Aguiar et al. 2017). The second stage (from 200 to $500{ }^{\circ} \mathrm{C}$ ) was a devolatilized and decomposed of hemicelluloses and cellulose at a fast rate (Ding et al. 2014). The last stage (above $500{ }^{\circ} \mathrm{C}$ ) is degradation of lignin and other organic matter with stronger chemical bonds (Cárdenas-Aguiar et al. 2017). The pyrolysis temperature is strongly correlated with changes in the structure and physicochemical properties of biochar (Asadullah et al. 2007; Chen et al. 2008; Jindo et al. 2014; Mukherjee et al. 2011). Data on these relationships are presented in Table 2. Pyrolysis temperature had a strong influence on biochars physicochemical properties (e.g. surface area, $\mathrm{pH}$ and functional groups) and it affected on the functions of biochar as a soil amendment (Ding et al. 2014). Higher pyrolysis temperature resulted in an increase of surface area, carbonized fractions, $\mathrm{pH}$ and volatile matter and a decrease of CEC and content of surface functional groups.

\subsection{Specific surface area}

It has been found that increasing pyrolysis temperature causes changes in biochar surface area and porosity (Bonelli et al. 2007). This is most likely due to the decomposition of organic matter and the formation of micropores (Katyal et al. 2003). Moreover, the destruction of aliphatic alkyls and ester groups as well as the exposure of the aromatic lignin core under higher pyrolysis temperatures may result in increased surface area (Chen and Chen 2009). Ghani et al. (2013) have shown that at lower temperatures (less than $500{ }^{\circ} \mathrm{C}$ ), lignin is not converted into a hydrophobic polycyclic aromatic hydrocarbon (PAH) and biochar becomes more hydrophilic. At temperatures higher than $650{ }^{\circ} \mathrm{C}$, biochar is thermally stable and becomes more hydrophobic (Ghani et al. 2013).

However, the hydrophobicity/hydrophilicity of the surface is not an unambiguous factor conditioning the sorption process of aromatic compounds. The surface area of the biochar increases with increasing temperature. This is because with increasing pyrolysis temperature, pore-blocking substances are driven off or are thermally cracked, increasing the externally accessible surface area (Rafiq et al. 2016). Pyrolysis may increase the surface area and pore volumes through progressive degradation of the organic materials (cellulose, lignin) and the formation of vascular 
Table 2 Biochar characteristic in different temperature from fruits and vegetables biomass

\begin{tabular}{|c|c|c|c|c|c|c|c|c|c|}
\hline $\mathrm{BF}$ & PT $\left({ }^{\circ} \mathrm{C}\right)$ & PY (\%) & $\mathrm{pH}$ & $\begin{array}{l}\text { SSA } \\
\left(\mathrm{m}^{2} / \mathrm{g}\right)\end{array}$ & VM $(\%)$ & $\mathrm{A}(\%)$ & $\begin{array}{l}\text { CEC } \\
(\mathrm{cmol} / \mathrm{kg})\end{array}$ & $\mathrm{C}(\%)$ & References \\
\hline Peanut shell & 300 & 36.9 & 7.8 & 3.1 & 60.5 & 1.2 & - & 68.3 & Ahmad et al. (2012) \\
\hline Peanut shell & 700 & 21.9 & 10.6 & 448.2 & 32.7 & 8.9 & - & 83.8 & \\
\hline Peanut straw & 700 & - & 11.2 & - & - & 38.5 & 254.0 & - & \\
\hline Dairy Manure & 350 & - & 9.2 & 1.6 & 53.5 & 24.2 & - & 55.8 & Cantrell et al. (2012) \\
\hline Dairy Manure & 700 & - & 9.9 & 186.5 & 27.7 & 39.5 & - & 56.7 & \\
\hline Feedlot manure & 350 & - & 9.1 & 1.34 & 47.9 & 28.7 & - & 53.3 & \\
\hline Feedlot manure & 700 & - & 10.3 & 145.2 & 19.8 & 44.0 & - & 52.4 & \\
\hline Poultry litter & 350 & - & 8.7 & 3.9 & 42.3 & 30.7 & - & 51.2 & \\
\hline Poultry litter & 700 & - & 10.3 & 50.9 & 18.3 & 46.2 & - & 45.9 & \\
\hline Separated swine solids & 350 & - & 8.4 & 0.9 & 49.8 & 32.5 & - & 51.5 & \\
\hline Separated swine solids & 700 & - & 9.5 & 4.1 & 13.4 & 52.9 & - & 44.0 & \\
\hline Turkey litter & 350 & - & 8.0 & 2.6 & 42.1 & 34.8 & - & 49.3 & \\
\hline Turkey litter & 700 & - & 9.9 & 66.7 & 20.8 & 49.9 & - & 44.8 & \\
\hline Dairy Manure & 100 & 97.0 & 8.0 & 1.8 & - & 37.0 & - & 36.8 & Cao et al. (2009) \\
\hline Dairy Manure & 200 & 58.0 & 6.8 & 2.7 & - & 44.0 & - & 31.1 & \\
\hline Dairy Manure & 350 & 27.0 & 10.5 & 7.1 & - & 62.0 & - & 25.2 & \\
\hline Dairy Manure & 500 & 25.0 & 10.5 & 13.0 & - & 95.0 & - & 1.7 & \\
\hline Prunings of fruit trees & 500 & - & 10.8 & - & 58.8 & 4.7 & - & - & Castellini et al. (2015) \\
\hline Cattle manure & 300 & - & 8.0 & - & 47.3 & 20.2 & 66.3 & - & Cely et al. (2015) \\
\hline Cattle manure & 500 & - & 10.2 & - & 13.2 & 43.7 & 70.9 & - & \\
\hline Cattle-straw manure & 300 & - & 10.1 & - & 24.9 & 38.3 & 65.5 & - & \\
\hline Cattle-straw manure & 500 & - & 10.1 & - & 11.9 & 51.3 & 58.4 & - & \\
\hline Chicken manure & 300 & - & 8.1 & - & 23.9 & 34.8 & 137.6 & - & \\
\hline Chicken manure & 500 & - & 10.6 & - & 11.9 & 38.0 & 81.4 & - & \\
\hline Chicken-sawdust manure & 300 & - & 10.6 & - & 13.0 & 34.6 & 81.7 & - & \\
\hline Chicken-sawdust manure & 500 & - & 10.3 & - & 8.3 & 35.9 & 65.8 & - & \\
\hline Pig manure & 300 & - & 7.8 & - & 31.3 & 50.3 & 35.6 & - & \\
\hline Pig manure & 500 & - & 8.2 & - & 6.50 & 73.9 & 32.7 & - & \\
\hline Corn straw & 600 & - & 9.5 & 13.1 & - & 60.2 & - & 35.9 & Chen et al. (2011) \\
\hline Hardwood & 450 & - & 5.6 & 0.4 & - & 38.6 & - & 53.4 & Chen et al. (2011) \\
\hline Municipal sewage sludge & 900 & 53.3 & 12.2 & 67.6 & 87.5 & 88.1 & 247.5 & 15.9 & Chen et al. (2015) \\
\hline Sugarcane bagasse & 400 & 31.6 & 7.0 & 0.8 & - & - & 3.8 & - & Ding et al. (2014) \\
\hline Sugarcane bagasse & 600 & 22.9 & 7.7 & 14.1 & - & - & 4.2 & - & \\
\hline Chicken Manure & 350 & 69.7 & 9.7 & - & 36.9 & 52.0 & - & 31.2 & Domingues et al. (2017) \\
\hline Chicken Manure & 450 & 63.0 & 10.2 & - & 30.6 & 55.3 & - & 27.2 & \\
\hline Chicken Manure & 750 & 55.9 & 11.7 & - & 26.5 & 56.4 & - & 24.7 & \\
\hline Eucalyptus sawdust & 350 & 42.5 & 5.9 & - & 36.9 & 0.9 & - & 70.4 & \\
\hline Eucalyptus sawdust & 450 & 36.0 & 8.0 & - & 28.5 & 0.7 & - & 78.6 & \\
\hline Eucalyptus sawdust & 750 & 28.2 & 9.7 & - & 6.5 & 1.1 & - & 90.9 & \\
\hline Coffee husk & 350 & 43.5 & 9.7 & - & 34.6 & 12.9 & - & 60.5 & \\
\hline Coffee husk & 450 & 37.7 & 9.8 & - & 26.2 & 12.9 & - & 61.3 & \\
\hline Coffee husk & 750 & 31.6 & 9.9 & - & 17.6 & 19.6 & - & 66.0 & \\
\hline
\end{tabular}


Table 2 continued

\begin{tabular}{|c|c|c|c|c|c|c|c|c|c|}
\hline $\mathrm{BF}$ & PT $\left({ }^{\circ} \mathrm{C}\right)$ & PY (\%) & $\mathrm{pH}$ & $\begin{array}{l}\text { SSA } \\
\left(\mathrm{m}^{2} / \mathrm{g}\right)\end{array}$ & VM (\%) & $\mathrm{A}(\%)$ & $\begin{array}{l}\text { CEC } \\
(\mathrm{cmol} / \mathrm{kg})\end{array}$ & $\mathrm{C}(\%)$ & References \\
\hline Sugarcane bagasse & 350 & 37.5 & 7.2 & - & 35 & 1.9 & - & 74.7 & \\
\hline Sugarcane bagasse & 450 & 33.2 & 8.8 & - & 24 & 2.1 & - & 81.6 & \\
\hline Sugarcane bagasse & 750 & 26.9 & 9.7 & - & 7.7 & 2.2 & - & 90.5 & \\
\hline Pine bark & 350 & 59.6 & 7.8 & - & 38.5 & 8.3 & - & 67.6 & \\
\hline Pine bark & 450 & 49.3 & 8.3 & - & 29.3 & 7.9 & - & 75.2 & \\
\hline Pine bark & 750 & 38.9 & 9.9 & - & 6 & 14.5 & - & 86.3 & \\
\hline Prosopis Africana shell & 350 & 60.1 & 6.5 & 3.1 & - & 25.2 & - & 70.8 & Elaigwu et al. (2014) \\
\hline Swine manure & 400 & 49.3 & 11.0 & 4.9 & 35.5 & 49.8 & 65.6 & 74.9 & Jin et al. (2016) \\
\hline Rapeseed plant & 400 & 39.4 & - & 16.0 & 27.1 & 12.2 & - & 71.3 & Karaosmanoglu et al. (2000) \\
\hline Rapeseed plant & 700 & 29.6 & - & 19.3 & 9.0 & 14.4 & - & 79.5 & \\
\hline Fescue straw & 100 & 99.9 & - & 1.8 & 69.6 & 6.9 & - & 48.6 & Keiluweit et al. (2010) \\
\hline Fescue straw & 700 & 28.8 & - & 139.0 & 9.1 & 19.3 & - & 94.2 & \\
\hline Cow manure & 400 & - & - & 2.5 & 27.4 & 15.3 & - & 60.2 & Kolodynska et al. (2012) \\
\hline Cow manure & 600 & - & - & 8.0 & 13.0 & 18.8 & - & 58.8 & \\
\hline Pig manure & 400 & - & - & 15.6 & 19.1 & 46.5 & - & 44.1 & \\
\hline Pig manure & 600 & - & - & 15.9 & 15.1 & 50.3 & - & 42.3 & \\
\hline Tire rubber & 200 & 93.5 & - & - & - & 15.0 & - & 74.7 & Lian et al. (2011) \\
\hline Tire rubber & 800 & 43.0 & - & 50.0 & - & 10.5 & - & 86.0 & \\
\hline Oak wood & 450 & - & - & 1.9 & 15.6 & 64.5 & - & 71.3 & Mohan et al. (2011) \\
\hline Corn cobs & 500 & 18.9 & 7.8 & 0 & - & 13.3 & - & 77.6 & Mullen et al. (2010) \\
\hline Corn stover & 500 & 17.0 & 7.2 & 3.1 & - & 32.8 & - & 57.3 & \\
\hline Poultry litter & 500 & - & - & 1.0 & 17.7 & 41.9 & - & 48.3 & Novak et al. (2009) \\
\hline Pine chip & 500 & - & - & 6.2 & 22.4 & 2.6 & - & 88.9 & Novak et al. (2016) \\
\hline Soybean stover & 700 & 29.6 & 11.3 & 420.3 & 14.7 & 17.2 & 59.2 & 82.0 & Karunanithi et al. (2017) \\
\hline Soybean straw & 700 & - & 11.1 & - & - & 23.7 & 222.0 & - & \\
\hline Corn stover & 300 & 66.2 & 7.7 & 3.2 & 54 & 5.7 & - & 45.5 & Rafiq et al. (2016) \\
\hline Corn stover & 400 & 37.1 & 8.8 & 3.2 & 45.5 & 12.5 & - & 64.0 & \\
\hline Corn stover & 500 & 29.2 & 9.8 & 4.6 & 33.8 & 18.7 & - & 64.5 & \\
\hline Orange pomace & 350 & 71.9 & 9.9 & 1.2 & 32.3 & 11.3 & 35.2 & 56.8 & Tag et al. (2016) \\
\hline Orange pomace & 600 & 44.6 & 10.5 & - & 17.3 & 16.3 & 25.6 & 68.1 & \\
\hline Vine pruning & 350 & 64.6 & 10.3 & 8.1 & 30.2 & 8.3 & 47.4 & 64.7 & \\
\hline Cottonseed hull & 350 & 36.8 & 7.0 & 4.7 & 34.9 & 5.7 & - & 77.0 & Uchimiya et al. (2011b) \\
\hline Cottonseed hull & 800 & 24.2 & 9.2 & 322.0 & 11.4 & 9.2 & - & 90.0 & \\
\hline Orange peel & 700 & 22.2 & - & 201.0 & - & 2.8 & - & 71.6 & \\
\hline Black wattle & 475 & - & 9.7 & 241.0 & - & 4.8 & 101.0 & 66.5 & Uras et al. (2012) \\
\hline Sugarcane bagasse & 475 & - & 6.6 & 259.0 & - & 12.1 & 122.0 & 57.3 & \\
\hline Vineyard prunings & 475 & - & 10.4 & 92.0 & - & 8.1 & 65.0 & 66.5 & \\
\hline Tree barks & 400 & - & 8.9 & - & - & - & 23.0 & 80.0 & Venegas et al. (2015) \\
\hline Rice straw & 300 & 50.1 & 9.3 & - & 48.4 & 25.4 & 60.6 & 72.5 & Wu et al. (2012) \\
\hline Rice straw & 700 & 33.5 & 10.8 & - & 14.9 & 28.2 & 23.1 & 90.6 & \\
\hline Bamboo & 450 & 26.3 & 5.2 & 18.2 & - & - & - & 76.9 & Yao et al. (2012) \\
\hline Bamboo & 600 & 24.0 & 7.9 & 470.4 & - & - & - & 80.9 & \\
\hline Canola straw & 300 & - & 6.5 & - & - & 10.7 & 199.0 & - & Yuan et al. (2011) \\
\hline
\end{tabular}


Table 2 continued

\begin{tabular}{|c|c|c|c|c|c|c|c|c|c|}
\hline $\mathrm{BF}$ & PT $\left({ }^{\circ} \mathrm{C}\right)$ & PY (\%) & $\mathrm{pH}$ & $\begin{array}{l}\text { SSA } \\
\left(\mathrm{m}^{2} / \mathrm{g}\right)\end{array}$ & VM (\%) & $\mathrm{A}(\%)$ & $\begin{array}{l}\text { CEC } \\
(\mathrm{cmol} / \mathrm{kg})\end{array}$ & $\mathrm{C}(\%)$ & References \\
\hline Canola straw & 700 & - & 10.8 & - & - & 28.6 & 179.0 & - & \\
\hline Buckwheat husk & 350 & 46.3 & 9.2 & 11.4 & - & 4.0 & 11.2 & 70.1 & Zama et al. (2017) \\
\hline Buckwheat husk & 450 & 42.3 & 9.7 & 10.7 & - & 25.4 & 11.5 & 76.5 & \\
\hline Buckwheat husk & 550 & 34.2 & 10.0 & 17.0 & - & 5.8 & 10.1 & 82.8 & \\
\hline Buckwheat husk & 650 & 28.5 & 9.1 & 17.8 & - & 33.1 & 11.7 & 83.9 & \\
\hline Mulberry wood & 350 & 37.5 & 10.2 & 16.6 & - & 7.5 & 23.3 & 67.9 & \\
\hline Mulberry wood & 450 & 32.7 & 11.1 & 31.5 & - & 7.7 & 22.1 & 70.8 & \\
\hline Mulberry wood & 550 & 26.2 & 10.6 & 58.0 & - & 9.8 & 19.0 & 77,0 & \\
\hline Mulberry wood & 650 & 22.8 & 10.6 & 24.5 & - & 9.8 & 21.8 & 80.1 & \\
\hline Peanut shells & 350 & 45.7 & 10.4 & 14.0 & - & 7.06 & 26.5 & 64.3 & \\
\hline Peanut shells & 450 & 38.1 & 11.1 & 14.0 & - & 16.9 & 23.7 & 70.8 & \\
\hline Peanut shells & 550 & 32.5 & 10.6 & 18.6 & - & 7.1 & 19.7 & 73.7 & \\
\hline Peanut shells & 650 & 29.4 & 10.6 & 28.1 & - & 24.4 & 17.4 & 74.6 & \\
\hline
\end{tabular}

$B F$ Biochar feedstock, $P T$ pyrolysis temperature, $S S A$ specific surface area, $V M$ Volatile matter, $A$ Ash, $P Y$ product yield, $C$ total carbon content, $C E C$ cation exchange capacity

bundles or channel structure (Li et al. 2013; Zhao et al. 2017). Some amorphous carbon structures also form during pyrolysis due to the degradation of cellulose (Zhao et al. 2017).It has been reported that micropores may be formed by amorphous carbon structures (Vamvuka and Sfakiotakis 2011). A higher pyrolysis temperature causes the release of volatile matter and creates more pores (Shaaban et al. 2014). Low specific surface areas with low ash content were observed in biochars produced from cotton seed hull $\left(4.7 \mathrm{~m}^{2} / \mathrm{g}\right)$ (Uchimiya et al. 2011b), poultry litter $\left(17.7 \mathrm{~m}^{2} /\right.$ g) (Novak et al. 2009) and dairy manures $\left(13.0 \mathrm{~m}^{2} /\right.$ g) (Cao and Harris 2010). The type and concentration of surface functional groups have been reported to play an important role in adsorption capacity and the removal mechanism of the adsorbates (YenisoyKarakaş et al. 2004). Moreover, an increase in the structure aromaticity with an increase in pyrolysis temperature can also enhance resistance to microbial decomposition (Xie et al. 2015). Uchimiya et al. (2010) discovered that biochar produced at a temperature higher than $400{ }^{\circ} \mathrm{C}$ was more effective for organic and inorganic contaminant sorption due to its high surface area and considerable micropore development. However, Chen et al. (2008) proved that the partitioning of organic and inorganic contaminants into non-carbonized biochar fractions derived from pine needles was the major sorption mechanism at low pyrolysis temperatures $\left(100-300{ }^{\circ} \mathrm{C}\right)$, whereas adsorption onto porous carbonized fractions was dominant at high temperatures $\left(400-700{ }^{\circ} \mathrm{C}\right)$.

\subsection{Surface Functional Groups and CEC}

The heating to temperatures of $350-650{ }^{\circ} \mathrm{C}$ breaks and rearranges the chemical bonds in the biomass, forming new functional groups (e.g. carboxyl, lactone, lactol, quinine, chromene, anhydride, phenol, ether, pyrone, pyridine, pyridone, and pyrrole) (Mia et al. 2017). Figures 1 and 2 shows example structures on the outer surface of the graphene sheets (Harris 1997; Harris and Tsang 1997) and pores (Van Zwieten et al. 2010; Zheng et al. 2010). The FTIR spectra indicate that biochar is dominated by functional groups typical of oxygenated hydrocarbons, reflecting the carbohydrate structure of cellulose and hemicelluloses (Ghani et al. 2013). The pyrolysis process can cause the disappearance of absorption bands characteristic of raw material and the appearance of new bands typical of biochar samples. Ghani et al. (2013) demonstrated that the biochar from sawdust exhibited a broad band between 3000 and $3600 \mathrm{~cm}^{-1}$ (peak maximum at $3339 \mathrm{~cm}^{-1}$ ), 
with a smaller band from 2700 to $3000 \mathrm{~cm}^{-1}$ (maximum at $2907 \mathrm{~cm}^{-1}$ ). The band centred at $3339 \mathrm{~cm}^{-1}$ was attributed to the presence of $\mathrm{OH}$ functional groups (alcoholic and phenolic) (Pretsch et al. 2009), while the band at $\sim 2907 \mathrm{~cm}^{-1}$ was attributed to alkyl C-H stretching (Claoston et al., 2014). The band occurring at $1600 \mathrm{~cm}^{-1}$ was attributed to aromatic $\mathrm{C}-\mathrm{C}$ and $\mathrm{C}-\mathrm{O}$ stretching of conjugated ketones and quinones (Ruthiraan et al. 2015), and the band occurring at $1735 \mathrm{~cm}^{-1}$ was attributed to $\mathrm{C}=\mathrm{O}$ stretching of ketones, aldehydes and esters (Uchimiya et al. 2011a). The band centred at $1238 \mathrm{~cm}^{-1}$ was attributed to the presence of $\mathrm{C}-\mathrm{O}-\mathrm{C}$ groups and aryl ethers, phenolic associated with lignin (Kardam et al. 2012). The intense band occurring at $1130 \mathrm{~cm}^{-1}$ was characteristic of $\mathrm{C}-\mathrm{O}-\mathrm{C}$ stretching of ester groups in cellulose and hemicelluloses (Jeba Jeevitha et al. 2015). All of these bands are typical for the FTIR of biochars (Claoston et al. 2014; Ghani et al. 2013; Liu et al. 2015; Kardam et al. 2012; Zhao et al. 2017).

The effect of temperature on biochar structure and functional groups is shown in Fig. 3. Biochar produced at high temperatures $\left(600-700{ }^{\circ} \mathrm{C}\right)$ exhibits a highly hydrophobic nature with well-organized $\mathrm{C}$ layers (Uchimiya et al. 2011a). However, it is characterized by lower contents of $\mathrm{H}$ - and $\mathrm{O}$-containing functional groups due to dehydration and deoxygenation of the biomass (Ahmad et al. 2014a; Uchimiya et al. 2011a). Surface groups can act as electron donors or electron acceptors, which leads to the formation of coexisting areas whose properties can range from acidic to basic and from hydrophilic to
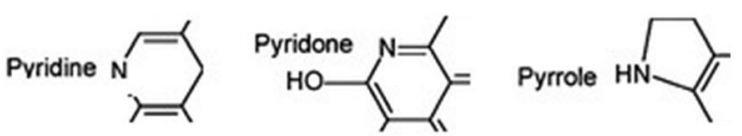

Fig. 2 Biochar surface functional basic groups

hydrophobic (Amonette and Joseph 2009). Consequently, such a product exhibits potentially lower ion exchange capacity (Novak et al. 2009). On the other hand, biochar produced at lower temperatures (300-400 ${ }^{\circ} \mathrm{C}$ ) displays more diversified organic character due to the occurrence of aliphatic and cellulose type structures (Glaser et al. 2002; Novak et al. 2009). As a result, the structure of biochar appears to have more organized $\mathrm{C}$ layers (like graphene structure) and less content of surface functional groups when pyrolysis temperature increases (Ahmad et al. 2014b).

The decrease in CEC is due to the removal of surface functional groups and the formation of aromatic carbon (Joseph et al. 2010). Numerous studies have reported that the cation exchange capacity (CEC) of biochar decreases with increasing pyrolysis temperature (Mukherjee et al. 2011; Song and Guo 2012; Yao et al. 2012). The detectable CEC suggested that when biochar was produced at temperatures up to $480{ }^{\circ} \mathrm{C}$, some acidic oxygenated functional groups such as phenolic acid and carboxyl groups were retained (Mitchell et al. 2013). Banik et al. (2018) reported that the CEC of biochar is dependent on the nature and distribution of O-containing functional groups on the biochar surface. The negative charge sites on biochar surfaces are attributed

Fig. 1 Biochar surface functional acidic groups

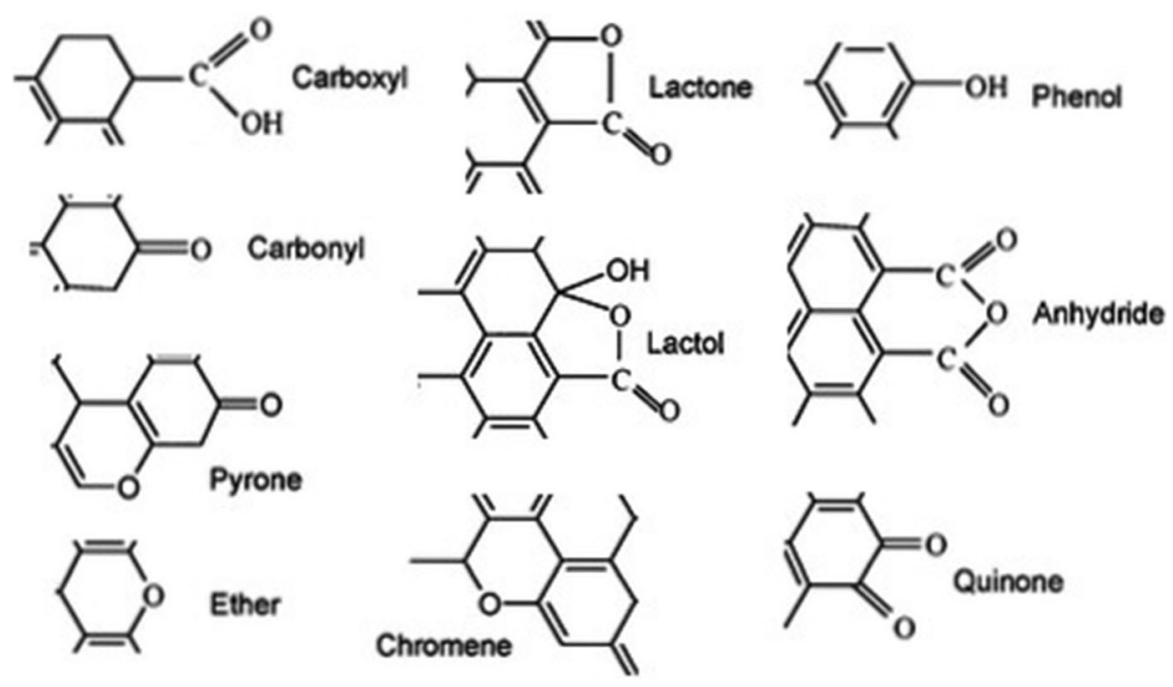




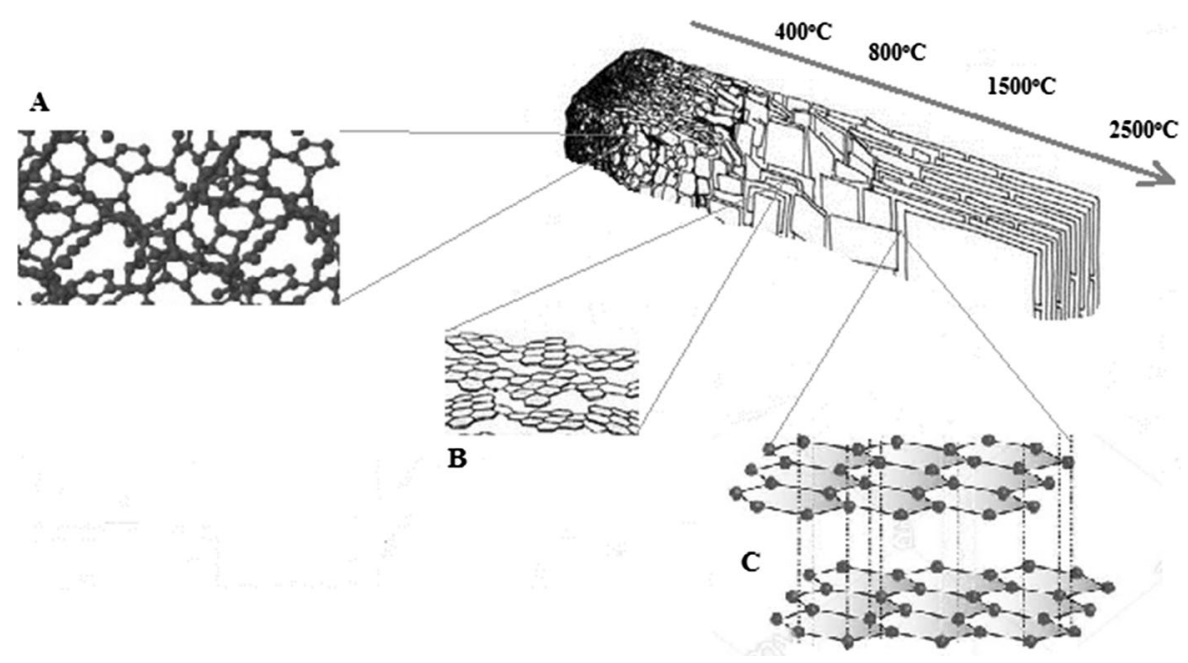

Fig. 3 Pyrolysis temperature effect on biochar: a amorphous carbon; b turbostratic carbon; $\mathbf{c}$ graphite carbon

to carboxylate and phenolate functional groups (Mia et al. 2017). They assume that negative surface charge can only come from carboxylate and phenolate groups and positive charge from oxonium groups (heteroatoms in aromatic rings) (Banik et al. 2018). However, other studies have found that biochars with higher specific surface area (obtained at temperatures above $600{ }^{\circ} \mathrm{C}$ ) have greater surface microporosity and increased CEC (Gomez-Eyles et al. 2013; Kasozi et al. 2010). This was caused by the loss of volatile matter (Cely et al. 2015; Song and Guo 2012).

\subsection{Volatile matter}

Pyrolysis temperature has an influence on the structure of biochar due to the release of volatiles and the formation and volatilization of intermediate melts (Shaaban et al. 2014). Increasing the temperature leads to a decreased content of volatile matter (VM) (Crombie et al. 2013; Tag et al. 2016). Zhao et al. (2017) reported that an increase in the pyrolysis temperature decreased the content of VM (by $60.8-14.9 \%$ ) for biochars obtained from apple tree branches. This was observed because the increasing temperature resulted in further cracking of the volatile fractions into low-molecular-weight liquids and gases instead of biochar (Ronsse et al. 2012). Furthermore, increasing temperature might result in the dehydration of hydroxyl groups and thermal degradation of cellulose and lignin (Zhang et al. 2015). Lowtemperature biochars contain labile hydroxyl, carbonyl, carboxyl and hemiacetal compounds, while high-temperature biochars contain pyranones, ethers and quinines (Bourke et al. 2007). Antal and Grønli (2003) reported the stepwise chemical changes of cellulose subjected to increasing temperature. Biochars were dominated by oligosaccharides during the first stage of the pyrolysis process (temperatures up to $250{ }^{\circ} \mathrm{C}$ ). Phenols and furans appeared in biochars as the temperature increased to $290{ }^{\circ} \mathrm{C}$. At temperatures above $290{ }^{\circ} \mathrm{C}$, the biochar consisted primarily of alkyl furans, benzenoid aromatics, and condensed aromatics. The volatile matter content of a biochar affects the stability of the material (Zimmerman 2010), its N availability (Deenik et al. 2010), plant growth (Deenik et al. 2010; Denyes et al. 2014) and its sorption capacity (Mukherjee et al. 2011). The volatile components fill micropores, dominating the surface of biochars, and are released from pores at higher production temperatures, making them accessible to ions (Mukherjee et al. 2011). The content of volatile matter can affect plant growth in two ways: toxic compounds such as phenol can inhibit root growth, while oligosaccharides, which are produced during the first two stages, can serve as a labile carbon for microbial decomposition (Fernandes and Brooks 2003).

\subsection{Carbon content and ash content}

The carbon and ash contents of biochar increase with increasing pyrolysis temperature (Chen et al. 2008; 
Fuertes et al. 2010). High carbon content suggests that biochars probably still contain a certain amount of original organic plant residues such as cellulose (Chun et al. 2004). Rafiq et al. (2016) reported that increased pyrolysis temperature caused an increase of $5.7-18.7 \%$ in ash content. The increase in the ash content resulted from progressive concentration of inorganic constituents and $\mathrm{OM}$ combustion residues (Cao and Harris 2010; Chen et al. 2014; Zhao et al. 2017). Also, Zama et al. (2017) explained the increases in $\mathrm{Mg}, \mathrm{Ca}, \mathrm{K}$, and $\mathrm{P}$ on biochars pyrolysed at high temperatures as being due to increased ash content (ranging from 4.0 to $33.1 \%$ ). Mineral matter forming ash remains in biochar following carbonization (Domingues et al. 2017; Özçimen and ErsoyMeriçboyu 2010). Increased carbon content (ranging from 62.2 to $92.4 \%$ ) with an increase in pyrolysis temperature occurs due to a higher degree of polymerization (Domingues et al. 2017), leading to a more condensed carbon structure in the biochar (Lehmann and Joseph, 2009). For example, the carbon content of orange pomace biochar increased with increasing pyrolysis temperature (ranging from 56.8 to $68.1 \%$ ) (Tag et al. 2016). Cantrell et al. (2012) observed that the carbon content of poultry litter biochar decreased with increasing pyrolysis temperature (ranging from 27.0 to $35.5 \%$ ). The greater the degree of formation of aromatic structures, the higher the resistance of the biochar to microbial degradation (Keiluweit et al. 2010). Biochars with high ash contents also tend to have greater amounts of PAHs and trace metals (Yargicoglu et al. 2015). Preliminary studies have indicated that rigorous control of the feedstock materials and pyrolysis conditions contributed to substantial reductions of the emission levels of atmospheric pollutants (e.g. PAHs, dioxins) and particulate matter associated with biochar production (Verheijen et al. 2010).

\section{$2.5 \mathrm{pH}$}

The $\mathrm{pH}$ values of biochars are positively correlated with the formation of carbonates and the contents of inorganic alkalis (Ding et al. 2014). These groups are the main cause of alkaline $\mathrm{pH}$ (Yuan et al. 2011). The contents of total base cations and carbonates have been reported to increase with increasing temperature, contributing to increased $\mathrm{pH}$ (ranging from 6.5 to 10.8) (Yuan et al. 2011). Higher $\mathrm{pH}$ with increasing temperature has been associated with the increases in ash content and oxygen functional groups that occur during pyrolysis (Ronsse et al. 2012; Spokas et al. 2012; Zhao et al. 2017). The disappearance of acidic functional groups $(-\mathrm{COOH})$ and appearance of basic functional groups are additional contributors (AlWabel et al. 2013). However, increases in $\mathrm{pH}$ occur primarily due to the separation of alkali salts from organic materials due to increased pyrolysis temperature (Ding et al. 2014; Yuan et al. 2011). Above $300{ }^{\circ} \mathrm{C}$, alkali salts begin to separate from the organic matrix, increasing the $\mathrm{pH}$ of the product. In contrast, cellulose and hemicelluloses decompose around 200-300 ${ }^{\circ} \mathrm{C}$, yielding organic acids and phenolic substances that lower the $\mathrm{pH}$ of the products ( $\mathrm{Yu}$ et al. 2014). The $\mathrm{pH}$ becomes constant at a temperature around $600{ }^{\circ} \mathrm{C}$ when all of the alkali salts are released from the pyrolytic structure (Shinogi and Kanri 2003).

\section{Effects of feedstock material}

Biomass is a complex biological, organic or nonorganic solid material derived from living or recently living organisms (Mohan et al. 2006). Various types of wastes, such as animal manure, waste paper, sludge and many industrial wastes, are also treated as biomass because, like natural biomass, these waste materials are also a mixture of organic and non-organic compounds and can be processed to obtain energy (Tripathi et al. 2016). Biomass is categorized into woody and non-woody biomass. Woody biomass primarily comprises residues from forestry and trees (Jafri et al. 2018). The characteristics of woody biomass are low moisture, low ash, high calorific value, high bulk density and less voidage (Jafri et al. 2018). Non-woody biomass consists of agricultural crops and residues, animal waste, urban and industrial solid waste (Jafri et al. 2018). It is considered to have high moisture and high ash content, lower calorific value, low bulk density and higher voidage (Jafri et al. 2018).

The moisture content has influence on biochar formation (Kloss et al. 2012; Sun et al. 2014). Moisture contained in biomass not only increases the energy required to reach the pyrolysis temperature, it also inhibits char formation (Tripathi et al. 2016) Biomass is always associated with some amount of water/moisture content. This water inside a biomass 
can exist as water vapour, chemically bound water (adsorbed within the pores of biomass) and free liquid water (Vassilev et al. 2013). Low moisture is advisable for the biochar production due to considerable reduction the heat energy and time required for the pyrolysis making the process economically viable as compared to pyrolysis involving biomass with high moisture content (Tripathi et al. 2016). Wide range of moisture content in biomass promotes production biochars with different physicochemical characteristics (Tripathi et al. 2016). For example, the moisture content of hardwood and softwood bark samples had a pronounced effect on the surface chemistry of the pyrolytic charcoals (Darmstadt et al. 2000). With decreasing maple bark moisture the charcoal surface becomes more polyaromatic and graphite-like, probably due to the longer effective pyrolysis time after the water has been evaporated (Darmstadt et al. 2000).

\subsection{Volatile matter, carbon content and ash content}

The lignin and cellulose content have influence on biochar formation (Kloss et al. 2012). Cellulose, present in the biomass, helps in the formation of tar (is a mixture of discrete ketones, aldehydes, organic liquids, and char), while high lignin content is favourable for char production during pyrolysis (Tripathi et al. 2016; Yu et al. 2014). El-Gamal et al. (2017) reported that the content of cellulose and hemicelluloses as well as moisture content of sugarcane bagasse were higher than rice husk, but rice husk biomass had higher content of lignin and ash. These can be attributed to the presence of different organic constituents in feedstock (El-Gamal et al. 2017). Lignin is amorphous and hydrophobic polymer with high molecular weight and numerous functional groups of aromatic substructure (Lee et al. 2013b). Cellulose and hemicelluloses are consisting of simple sugar monomer, which decompose at a temperature lower than $450{ }^{\circ} \mathrm{C}$ (Lee et al. 2013b). These two compounds have lower molecular weight than lignin and are easily released as pyrolytic vapors (Lee et al. 2013a), while lignin is very resistant to thermal degradation. Shariff et al. (2016) shows that coconut frond feedstock had higher cellulose $(39.1 \%)$ and hemicelluloses $(22.5 \%)$ content than coconut huskbiochar (33.6 and 22.0\%). Coconut husk-feedstock had also higher lignin content $(28.2 \%)$ than coconut frond feedstock (21.5\%). Shariff et al. (2016) observed that the variations of lignocellulosic component in the feedstock influence biochar production. The high lignin composition in the feedstock will result in higher char formation (Demirbas 2004). This indicated that production of biochar will be increased with increased lignin content in feedstock (Shariff et al. 2016).

The higher lignin content in plant biomass has been reported to promote carbonization and to increase biochar carbon content and ash content (Sohi et al. 2010; Wang et al. 2015). Other studies of biomass structure have revealed that cellulose and hemicelluloses also have a significant influence on the carbon and ash contents (Rauber et al. 2018; Tripathi et al. 2016). Keiluweit et al. (2010) investigated different biochars derived from grass and wood biomass. Woody biomass often has higher cellulose, hemicellulose and lignin contents (Fig. 4) than biomass from herbaceous or grass species (Keiluweit et al. 2010; Lupoi and Smith 2012). However, apart from the lignin, cellulose and hemicellulose, a high yield of pyrolysis is also related to a high content of inorganic constituents of the feedstock materials, as indicated by their relatively high ash content and low content of volatile matter (Keiluweit et al. 2010). For example wood derived biochars have lower ash content $(<7.0 \%)$ in comparison to non-wood-derived biochars (>50.0\%) (Mukome et al. 2013). Singh and Cowie (2010) observed lower ash content in eucalyptus-derived biochar compared to poultry litter and cow manure. Manure and grass biochars typically have higher ash contents due to the presence of silica from soil contamination (Mukome et al. 2013). The low ash content makes biochar more amenable to transportation and incorporation into soils, as there is less windblown loss (Mukome et al. 2013). Additionally, Zhang et al. (2019) shows that the ash content was the lowest in woody biochars $(1.5-3.0 \%)$ and the highest in peanut shell biochars (7.0-12.0\%). Selection of woodbiochars would limit the increase in soil ash content, which has been associated with increased hydrophobicity (Kookana et al. 2011). An increase in hydrophobicity causes potential retention of hydrophobic agrochemicals, such as the herbicides (Sopeña et al. 2012). Zielińska et al. (2015) shows that sewage sludge derived-biochars were characterized by high ash content (ranged from 64.1 to $79.1 \%$ ). This results 


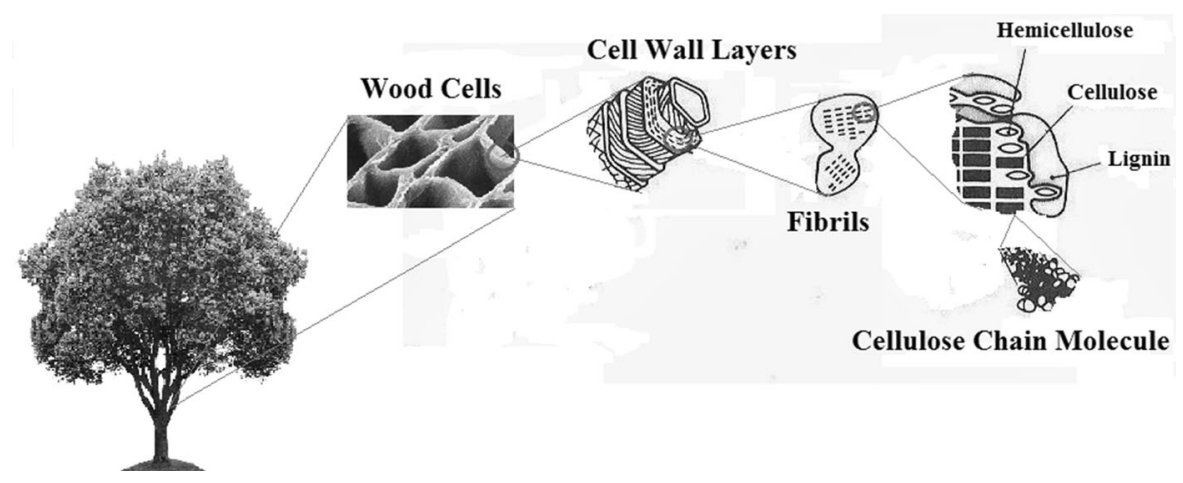

Fig. 4 How wood is composed of cellulose

from complexity and diversity of components contained in biomass (Zielińska et al. 2015).

Different biochars clearly demonstrate that plantbased biomass undergoes dehydration and depolymerization into smaller dissociation products of lignin and cellulose with an increase in pyrolysis temperature (Keiluweit et al. 2010). However, biochars derived from poultry manure and sewage sludge do not undergo depolymerisation due to the absence of lignocellulosic compounds (Liu et al. 2014; Lu et al. 2012). Biochars produced from animal litter and solid waste feedstocks exhibit lower surface areas compared to biochars produced from crop residue and wood biomass, even at higher pyrolysis temperatures ( $\mathrm{Lu}$ et al. 2012). This may be due to the low $\mathrm{C}$ content, low volatile matter content and high molar $\mathrm{H} / \mathrm{C}$ and $\mathrm{O} / \mathrm{C}$ ratios in the latter biomass samples, leading to the formation of extensive cross-linkages (Bourke et al. 2007). Chen et al. (2008) showed that decreased H/C and $\mathrm{O} / \mathrm{C}$ ratios were related to a higher aromaticity and lower polarity of biochars derived from pine needles. Tag et al. (2016) observed the highest carbon content in the linogcellulosic biochar (vine pruning-72.3\%; orange pomace- $68.1 \%$ and poultry litter-56.6\%) and the lowest in the algal biochar $(45.1 \%)$ at $600{ }^{\circ} \mathrm{C}$. Zielińska et al. (2015) shows that sewage sludgebiochar had lower carbon content (ranged from 18.1 to $27.8 \%$ ). An increase of carbon content is associated with the loss of $-\mathrm{OH}$ surface functional groups as a result of dehydration (Zielińska et al. (2015) however different types of biomass behave differently, which is result of a different kind of graphitization of carbon into well-organized layers (Uchimiya et al. 2011b). Volatile matters of biochars decreased and fixed carbon of biochars increased differently depending on ash content of biomass and biomass type (Tag et al. 2016). This is due to the fact that the volatile matter fraction of combustible carbon inside the biomass decreased. This occurred because the organic compounds in animal waste are more labile and (compared to wood biochars) are more rapidly lost as pyrolysis temperature increases, before the formation of biochar recalcitrant compounds (Domingues et al. 2017).

\subsection{Specific surface area}

Specific surface area is one of the most important properties of biochar and is dependent on feedstock type (Chen et al. 2011; Wang et al. 2015). Tag et al. (2016) discovered that biochars obtained from orange pomace and vine pruning, with low ash content, had low surface area $\left(1.2 \mathrm{~m}^{2} / \mathrm{g}\right.$ and $\left.8.1 \mathrm{~m}^{2} / \mathrm{g}\right)$. Probably this means that the pores within those biochars were dead-ended (Sharma et al. 2004). Type of feedstock causes the release of volatile matter and creates more pores (Shaaban et al. 2014). The increase in the porosity of biochar is due to the decomposition of lignin, the quick release of $\mathrm{H}_{2}$ and $\mathrm{CH}_{4}$ and the reaction of aromatic condensation as the temperature increases (Chen et al. 2012; Zhao et al. 2017). Kajina and Rousset (2018) reported that biochar produced from sugar cane leaves had a higher pore size $\left(0.1 \mathrm{~m}^{2} /\right.$ g) and specific surface area $\left(253.2 \mathrm{~m}^{2} / \mathrm{g}\right)$ than biochar produced from coconut shell (total pore size $=0.1 \mathrm{~m}^{2} /$ $\mathrm{g}$ and specific surface area $=25.8 \mathrm{~m}^{2} / \mathrm{g}$ ). El-Gamal et al. (2017) observed also that sugarcane-biochar had higher pore size $\left(0.1 \mathrm{~m}^{2} / \mathrm{g}\right)$ and specific surface area $\left(185.6 \mathrm{~m}^{2} / \mathrm{g}\right)$ than rice husks-biochar (total pore size $=0.1 \mathrm{~m}^{2} / \mathrm{g}$ and specific surface area $=154.7 \mathrm{~m}^{2} /$ $\mathrm{g})$.This indicates different thermal degradation and 
content of lignin and cellulose (El-Gamal et al. 2017). This was also confirmed by Apaydın-Varol and Pütün (2012). They reported that pine cone-biochars $\left(1.8 \mathrm{~m}^{2} / \mathrm{g}\right)$ and peanut shell-biochars $\left(2.0 \mathrm{~m}^{2} / \mathrm{g}\right)$ have higher surface area compared with soybean cakebiochar $\left(0.5 \mathrm{~m}^{2} / \mathrm{g}\right)$ and corn stalk-biochar $\left(0.8 \mathrm{~m}^{2} / \mathrm{g}\right)$. This can be also attributed to the presence of high amounts of lignin in the biomass samples (Raveendran and Ganesh 1998). Özçimen and Ersoy-Meriçboyu (2010) shows that porosity, total pore volume and specific surface area values of biochar derived from apricot stone $\left(0.1 \%, 0.2 \mathrm{ml} / \mathrm{g}\right.$ and $\left.11.6 \mathrm{~m}^{2} / \mathrm{g}\right)$, derived from hazelnut shell $\left(0.1 \%, 0.1 \mathrm{ml} / \mathrm{g}\right.$ and $\left.14.7 \mathrm{~m}^{2} / \mathrm{g}\right)$ and derived from grape seed $(0.1 \%, 0.2 \mathrm{ml} / \mathrm{g}$ and $14.5 \mathrm{~m}^{2} / \mathrm{g}$ ) were found higher than their biomass from apricot stone $\left(0.1 \%, 0.1 \mathrm{ml} / \mathrm{g}\right.$ and $\left.10.5 \mathrm{~m}^{2} / \mathrm{g}\right)$, from hazelnut shell $\left(0.1 \%, 0.1 \mathrm{ml} / \mathrm{g}\right.$ and $\left.5.8 \mathrm{~m}^{2} / \mathrm{g}\right)$, and from grape seed $\left(0.1 \%, 0.1 \mathrm{ml} / \mathrm{g}\right.$ and $\left.10.6 \mathrm{~m}^{2} / \mathrm{g}\right)$. The difference can be attributed to the different degradation of cellulose or lignin.

Surface area increases during pyrolysis due to the decomposition of cellulose and hemicelluloses, and the formation of channel structures (Ahmad et al. 2012). The non-combustible component content depends on the feedstock material and has an influence on the specific surface area (Wang et al. 2015). The non-combustible component corresponds to the moisture and ash content (Pichtel 2014). The non-combustible component content of the herbaceous biochar was higher than that of the woody biochar, which can be attributed to the fact that grass biochar, has a lower specific surface area (Wang et al. 2015). The lower surface area is also probably due to inorganic material that partially fills or blocks the micropores (Lee et al. 2010). Ronsse et al. (2012) observed that higher amount of inorganic (i.e. ash content) in the biomass feedstock negatively correlate with specific surface area in the biochars. Wood-biochar offers the highest potential of surface area $\left(127.0 \mathrm{~m}^{2} / \mathrm{g}\right)$ as all other biochar types (straw-biochar: $22.0 \mathrm{~m}^{2} / \mathrm{g}$; green wastebiochar: $46.0 \mathrm{~m}^{2} / \mathrm{g}$; algae-biochar: $19.0 \mathrm{~m}^{2} / \mathrm{g}$ ). Woodbiochar had the lowest ash content $(0.2 \%)$ than strawbiochar $(7.9 \%$, green waste-biochar $(3.5 \%)$ and algaebiochar (38.4\%). This is possibly explained by fusion of molten ash filling up pores in the biochar, thereby decreasing accessible surface area (Ronsse et al. 2012). Darmstadt et al. (2000) observed higher surface area for the softwoods $\left(326.0 \mathrm{~m}^{2} / \mathrm{g}\right)$ than the hardwoods $\left(221.0 \mathrm{~m}^{2} / \mathrm{g}\right)$ feedstock. The higher surface area of the charcoal produced from softwood bark may be explained by a partial activation of this sample by the water present in the feedstock and by creation of voids by evolving steam (Darmstadt et al. 2000). The less dense composition of the softwoods renders the more susceptible to thermal decomposition, resulting in more vesicles and pores throughout the wood structure, which effectively increases the surface area (Mukome et al. 2013),

\subsection{CEC}

The CEC of biochar depends on the type of feedstock. For example, the CEC of biochars derived from pig manure $(32.7 \mathrm{cmol} / \mathrm{kg})$ was lower than that of biochars produced from chicken manure $(81.4 \mathrm{cmol} . \mathrm{kg})$ at $500{ }^{\circ} \mathrm{C}$ (Cely et al. 2015). However, the CEC of biochars derived from paper mill waste (9.0-18.0 $\mathrm{cmol} / \mathrm{kg}$ ) (Van Zwieten et al. 2010) was significantly lower than the CEC of biochars derived from sugar cane bagasse (122.0 cmol/kg) (Carrier et al. 2012). This difference was observed because biomass with a high content of ash can produce biochar with a higher CEC (Yang et al. 2015). The reason for this ability might be that alkali and alkali metals in biomass promote the formation of O-containing surface functional groups (Cely et al. 2015; Tag et al. 2016). Thus, the CEC of manure-derived biochar is higher than that of woody biochar (Tag et al. 2016). Tag et al. (2016) observed that CEC was the highest in algal $(57.5 \mathrm{cmol} /$ $\mathrm{kg})$ and poultry litter $(48.4 \mathrm{cmol} / \mathrm{kg})$ derived biochars and the lowest in biochars produced from orange pomace $(29.9 \mathrm{cmol} / \mathrm{kg})$ at $500{ }^{\circ} \mathrm{C}$. Non-wood-derived biochars had increased CEC and surface acidity when compared to the wood biochars (Mukome et al. 2013). Similar results were reported by Gaskin et al. (2008), who found a significantly higher CEC for biochar from poultry litter $(38.3 \mathrm{cmol} / \mathrm{kg})$ than for biochars produced from peanut hulls $(4.6 \mathrm{cmol} / \mathrm{kg})$ and pine chips $(5.0 \mathrm{cmol} / \mathrm{kg})$ at $500{ }^{\circ} \mathrm{C}$. This decrease could be in part due to the reduction of the content of oxygenated functional groups on the biochar surface (Singh and Cowie 2010). Suliman et al. (2016) observed that biochars derived from Douglas fir wood had higher CEC than Douglas fir bark-biochar and hybrid poplarbiochar. This difference could be attributed to the combination of carboxylic functional groups, which contribute most of the CEC among the acidic 
functional groups, and specific surface area (Singh and Cowie 2010).

\section{$3.4 \mathrm{pH}$}

The $\mathrm{pH}$ of biochars is generally alkaline (from 7.1 to 10.5) (Inyang et al. 2010; Lehmann et al. 2011). Yuan et al. (2011) reported that biochars produced from corn straw, peanut and soybean (at a temperature of $300{ }^{\circ} \mathrm{C}$ ) were alkaline $(9.4,8.6$ and 7.7 , respectively), while the $\mathrm{pH}$ values of biochar produced from canola straw were acidic (around 6.5). Differences in $\mathrm{pH}$ can result from biomass type. Biochar produced from wood has an average $\mathrm{pH}$ lower by $2 \mathrm{pH}$ units than the values for other biomasses formed under similar pyrolysis conditions (Tag et al. 2016). Mukome et al. (2013) reported that non-wood-derived biochars have higher $\mathrm{pH}$ values (about 3.4 units). The basicity of the non-wood-derived biochar arises from the presence of salts (carbonates and chlorides of potassium and calcium in the ash) (Montes-Morán et al. 2004). El-Gamal et al. (2017) reported that the $\mathrm{pH}$ value of sugar cane-biochar (8.6) was lower than rice husks-biochar (8.9). This result could be due to the sugar cane-biochar $(19.1 \%)$ had lower ash content than rice husks-biochar (40.2\%). Increase of the $\mathrm{pH}$ value could be attributed to the concentration of nonpyrolyzed inorganic elements and also to decomposition of organic matrix (Garcia-Jaramillo et al. 2015).

The $\mathrm{pH}$ of a biochar is likely to be correlated with its contents of lignin, hemicelluloses or cellulose and the presence of oxygen functionalities (Ronsse et al. 2012). Yuan et al. (2011) reported that the -COO- and -O- groups and the carbonate content of the biochars were responsible for the alkaline properties. Mukome et al. (2013) shows that biochar $\mathrm{pH}$ correlated best with $\mathrm{O}$ content $\left(\mathrm{R}^{2}=0.7\right)$, corroborating previous findings that biochar basicity resulted from oxygenrich functional groups such as $\gamma$-pyrone-type, chromene, diketone, or quinine groups (Montes-Morán et al. 2004). The formation of compounds such as levoglucosan (from pyrolysis of cellulose material) and its by products (levoglucosenone, furfural, 2,3butanedione and 5-methylfurfural) results in oxygen functional groups during the pyrolysis (Kawamoto and Saka 2003). This process is associated with the polymerization/condensation reactions of aliphatic compounds and with the effect of the dehydration of the feedstock (Zielinska et al. 2015). Additionally, Li et al. (2013) reported that $\mathrm{pH}$ of biochars derived from rice straw and rice bran was negatively correlated with aliphatic O-alkylated carbons and anomeric $\mathrm{O}-\mathrm{C}-\mathrm{O}$ carbons, but positively correlated with fused-ring aromatic structures and aromatic $\mathrm{C}-\mathrm{O}$ groups. Consequently, a larger amount of carboxyl groups in the obtained biochar that are reduced during pyrolysis and/or acidic groups that become deprotonated to the conjugated bases result in a more alkaline $\mathrm{pH}$ of the biochar (Tag et al. 2016).

\section{Biochar influence on soil quality}

Biochar interacts physically with the soil fractions (Verheijen et al. 2010). Sub-molecular interactions with clay and silt particles, as well as with SOM (soil organic matter), occur through van der Waals forces and hydrophobic interactions (Xueyong et al. 2018). Interactions at this scale determine the influence of biochar on soil psychochemical properties and also on the interactions with cations, anions and other organic compounds in the soil (Zhu et al. 2017). These interactions are very specific for biochar, with the exact properties being influenced by feedstock type and pyrolysis conditions (Janus et al. 2015; Verheijen et al. 2010). Application of biochar can have positive or negative effects on soil properties, including water holding capacity (Revell et al. 2012), CEC (Alburquerque et al. 2014), bulk density (Cabeza et al. 2018), and specific surface area (Tomczyk et al. 2019). Data from a few experiments concerning the application of biochar as a soil amendment in different doses on different soil types are presented in Table 3. Higher biochar stability is not only useful from a climate mitigation point of view but also for maintaining possible positive agronomic effects over longer periods of time (Enders et al. 2012).

\subsection{Physicochemical properties of soil}

Biochar application to soils has been proposed as one of the best techniques for climate change mitigation via $\mathrm{C}$ sequestration in soil (Lehmann et al. 2006). The long-term stability of biochar in soil is a key factor affecting the decrease of $\mathrm{CO}_{2}$ emissions into the atmosphere (Cheng et al. 2008). A recent long-term experiment estimated that the mean residence time of $\mathrm{C}$ in biochars varies from 90 to 1600 years depending 
Table 3 Experiments about using of biochar as soil amendment in different doses on different soil type

\begin{tabular}{|c|c|c|c|c|}
\hline References & Feedstock kind & Pyrolysis temperature & Soil type (layer depth) & Biochar dose \\
\hline Ameloot et al. (2013) & $\begin{array}{l}\text { Willow wood } \\
\text { Swine manure }\end{array}$ & $\begin{array}{l}350{ }^{\circ} \mathrm{C} \\
700{ }^{\circ} \mathrm{C}\end{array}$ & $\begin{array}{l}\text { Sandy } \\
\text { loam soil }\end{array}$ & $10.0 \mathrm{Mg} / \mathrm{ha}$ \\
\hline Jin et al. (2016) & Swine manure & $400{ }^{\circ} \mathrm{C}$ & $\begin{array}{l}\text { Silt loam soil } \\
\text { Clay loam soil } \\
(0-15 \mathrm{~cm})\end{array}$ & 0.5 and $1.5 \%$ \\
\hline Mierzwa-Hersztek et al. (2016) & Poultry litter & $300{ }^{\circ} \mathrm{C}$ & $\begin{array}{l}\text { Eutric Cambisol } \\
(0-10 \mathrm{~cm})\end{array}$ & 2.3 and $5.0 \mathrm{t} / \mathrm{ha}$ \\
\hline Novak et al. 2009 & $\begin{array}{l}\text { Peanut hulls } \\
\text { Pecan shells } \\
\text { Poultry litter } \\
\text { Switchgrass }\end{array}$ & $250-700{ }^{\circ} \mathrm{C}$ & $\begin{array}{l}\text { Loamy sand } \\
(0-15 \mathrm{~cm})\end{array}$ & $\begin{array}{l}2.0 \% \\
(40-44 \mathrm{t} / \mathrm{h})\end{array}$ \\
\hline Novak et al. (2016) & $\begin{array}{l}\text { Poultry litter } \\
\text { Pine chip } \\
\text { Blends of the pine chip } \\
\text { Poultry litter }\end{array}$ & $500{ }^{\circ} \mathrm{C}$ & $\begin{array}{l}\text { Fine loamy } \\
\text { Kaolinitic } \\
\text { Thermic } \\
\text { Typic Kandiudult } \\
(20-40 \mathrm{~cm})\end{array}$ & $20.0 \mathrm{~g} / \mathrm{kg}$ \\
\hline Ouyang et al. (2014) & $\begin{array}{l}\text { Fresh dairy manure } \\
\text { Pine tree } \\
\text { Woodchip }\end{array}$ & $\begin{array}{l}300{ }^{\circ} \mathrm{C} \\
500{ }^{\circ} \mathrm{C} \\
700{ }^{\circ} \mathrm{C}\end{array}$ & $\begin{array}{l}\text { Forest } \\
\text { loamy sand }\end{array}$ & $5.0 \%$ \\
\hline Tomczyk et al. (2019) & Wood waste & $650{ }^{\circ} \mathrm{C}$ & $\begin{array}{l}\text { Haplic Luvisol } \\
\text { Haplic Podzol }\end{array}$ & $0,0.01,0.05,0.1 \%$ \\
\hline Usowicz et al. (2016) & Wood waste & $360{ }^{\circ} \mathrm{C}$ & $\begin{array}{l}\text { Haplic Luvisol } \\
(0-20 \mathrm{~cm})\end{array}$ & $10.0,20.0,30.0 \mathrm{Mg} / \mathrm{ha}$ \\
\hline Yao et al. (2012) & $\begin{array}{l}\text { Sugarcane bagasse } \\
\text { Peanut hull } \\
\text { Brazilian pepperwood } \\
\text { Bamboo }\end{array}$ & $\begin{array}{l}300{ }^{\circ} \mathrm{C} \\
450{ }^{\circ} \mathrm{C} \\
600{ }^{\circ} \mathrm{C}\end{array}$ & Sandy soil & $2.0 \%$ \\
\hline Zheng et al. (2010) & $\begin{array}{l}\text { Corn cobs } \\
\text { Wood chips }\end{array}$ & $450{ }^{\circ} \mathrm{C}$ & $\begin{array}{l}\text { Silt loam } \\
(0-10 \mathrm{~cm})\end{array}$ & $40.0 \mathrm{t} / \mathrm{ha}$ \\
\hline
\end{tabular}

on the labile and intermediate stable $\mathrm{C}$ components (Singh et al. 2012). The changes in functional groups and their distribution in soil microaggregates are influenced by the presence of biochar, this being indicative of changes in the physical protection and processing of $\mathrm{C}$ in soil (Hernandez-Soriano et al. 2016). A few recent studies have shown that biochar can reduce nitrous oxide $\left(\mathrm{N}_{2} \mathrm{O}\right)$ and methane $\left(\mathrm{CH}_{4}\right)$ emissions from soil via both biotic and abiotic mechanisms (Jha et al. 2010; Sun et al. 2018; Van Zwieten et al. 2009). Woolf et al. (2010) proposed a sustainable biochar concept, through which the emission of greenhouse gases including $\mathrm{CH}_{4}$ and $\mathrm{N}_{2} \mathrm{O}$ can be avoided. Additionally, the bioenergy produced during the pyrolysis process offsets fossil energy consumption (Woolf et al. 2010).

Furthermore, biochars are abundant in mineral elements such as $\mathrm{Na}, \mathrm{K}, \mathrm{Ca}, \mathrm{Fe}$ and $\mathrm{Mg}$ (Jha et al. 2010). Their concentrations increase with the pyrolysis temperature (Saletnik et al. 2016) and vary with the type of biomass (de la Rosa et al. 2014). In one study, the highest contents of $\mathrm{P}, \mathrm{K}$ and $\mathrm{Mg}$ (4.3, 9.9 and $2.8 \mathrm{~g} / \mathrm{kg}$, respectively) were observed in the biochar obtained at the temperature of $500{ }^{\circ} \mathrm{C}$, while the temperature of $400{ }^{\circ} \mathrm{C}$ resulted in the maximum contents of carbon and nitrogen $(73.6 \%$ and $1.9 \%$, respectively) (Saletnik et al. 2016). Cantrell et al. (2012) suggested that the various metals inherent in 
animal litter may protect against the loss of volatile material by changing the dissociation energies of organic and inorganic $\mathrm{C}$ bonds. The addition of biochar to the soil should increase the concentrations of micronutrients that are easily available to plants (Alburquerque et al. 2014; Jha et al. 2010). Improvement of soil physical, chemical, and biological properties promotes plant productivity through increasing the amount and availability of nutrient elements, reducing nutrient leaching and mitigating losses of gaseous components (Ding et al. 2016). It is widely known that a high CEC corresponds to high nutrient contents (Liang et al. 2006). Guo et al. (2012) showed that biochar has a high CEC and is expected to retain more nutrients in soil and to decrease nutrient leaching.

Glaser et al. (2002) suggested the oxidation of aromatic $\mathrm{C}$ and formation of carboxyl groups to be the main reason for high CEC. This formation of carboxyl groups or other functional groups with a negative charge in the $\mathrm{pH}$ range of soils can be the result of two principally different processes: (1) surface oxidation of the biochar particles themselves and (2) adsorption of highly oxidized organic matter onto biochar surfaces (Lehmann et al. 2005). Low-temperature biochars are often employed due to more enhanced soil-biochar interactions in relation to high-temperature biochars (Joseph et al. 2010). Such low-temperature biochar also yields a greater recovery of $\mathrm{C}$ and other nutrients (feedstock dependent), which are usually lost at higher temperatures (Keiluweit et al. 2010). The low-temperature product, which has been pyrolysed between 400 and $500{ }^{\circ} \mathrm{C}$, has its main advantage in increasing CEC. Furthermore, this biochar type sequesters soil $\mathrm{C}$, however, not to the same extent as high-temperature biochar (Antal and Grønli 2003). High-temperature biochars consequently have lesser reactivity in soils than lowertemperature biochars, which tend to have a better impact on soil fertility (Antal and Grønli 2003; Steinbeiss et al. 2009). Liang et al. (2006) reported that the CEC was up to 1.9 times higher in Anthrosols with a high biochar concentration than in control soils. The same results were obtained by Sombroek et al. (1993). The changes in soil properties that occur with biochar amendments, such as increases in organic carbon, the contents of mineral elements and values of CEC have an influence on soil pH (Rutkowska et al. 2014). Hass et al. (2012) observed that the effect of biochar on soil $\mathrm{pH}$ increased with application rate and varied among different types of biochar. The increases in $\mathrm{pH}$ and the corresponding reduction in exchangeable Al could also have improved the chemical environment (e.g. soil $\mathrm{pH}$, soil organic matter, phosphorus $(\mathrm{P})$ or potassium $(\mathrm{K})$ contents) of the biocharamended soils for radish plants (Abdulaha-Al Baquy et al. 2017). Chan et al. (2007) reported that the $\mathrm{pH}$ increases were accompanied by a significant reduction in exchangeable $\mathrm{Al}$ by $>50.0 \%$ at the higher rates of biochar application, i.e., 50.0 and 100.0 t/ha.

Application of biochar can have a positive effect on another physicochemical property of soil: specific surface area (Anawar et al. 2015). Liang et al. (2006) reported that Anthrosols had a (up to 4.8 times) higher surface area than other soils due to their higher biochar concentrations. Similarly, Tomczyk et al. (2019) showed that the specific surface area of the nonmodified silty Haplic Luvisol soil is almost three times higher than that of the sandy Haplic Podzol soil; amendment with biochars led to an increase of the specific surface area values in both soils. Modified Haplic Luvisol had a higher surface area due to higher biochar content (approx. 12.7-21.9 $\mathrm{m}^{2} / \mathrm{g}$ ) than the non-modified loamy soil and modified Haplic Podzol also had higher surface area due to higher biochar content (approx. $2.5-11.6 \mathrm{~m}^{2} / \mathrm{g}$ ) than the non-modified sandy soil. This suggests that Haplic Podzol had weaker interactions with than Haplic Luvisol. The larger specific surface area of Haplic Luvisol soil may be the result of the higher amounts of organic carbon as well as clay and silt materials in Haplic Luvisol in comparison to Haplic Podzol soil. Effect of biochar on soil specific surface area varies among biochar types. Lei and Zhang (2013) reported that wood biochar has a higher specific surface area $\left(124.0 \mathrm{~m}^{2} / \mathrm{g}\right)$ than biochar from the dairy industry $\left(83.4 \mathrm{~m}^{2} / \mathrm{g}\right)$. The application of biochar has been observed to increase the amount of macropores (with a maximum increase of 59.0\%), and the amount of macropores in biochar increases with the pyrolysis temperature (Kutilek et al. 2006; Lei and Zhang 2013). The increase of specific surface area and porosity caused better water sorption (Nair et al. 2017).

Fertilization with biochar also has a positive effect on water holding capacity (Duong et al. 2017). Biochar can absorb water up to 5.0 times its own weight (Gạsior and Tic 2017). Biochar can increase the moisture and content of organic and inorganic 
nitrogen compounds, which reduces lime in the litter, thereby reducing the $\mathrm{pH}$ of the litter and manure, which in turn reduces ammonia emissions (Gerlach 2014). Some studies have also shown how biochar changes water retention in soil. The increase in carbon content achieved by adding biochar to the soil contributes to stimulating the humification and carbon sequestration processes as well as the improvement of soil density and water retention (Nair et al. 2017). Cybulak et al. (2016) reported that the application of biochar increases the hygroscopic moisture content of soil (by about 1.5-3.0\%), which would be very beneficial to dry and degraded soils. Smaller biochar particle sizes can also increase water retention but may reduce saturated flow (Blanco-Canqui 2017). However, Glaser et al. (2002) reported that Amazonian charcoal-rich anthrosols had a field water retention capacity $18.0 \%$ higher than that of surrounding soil without charcoal. It can be expected that charcoal addition may cause an increase or decrease in the water retention of soils, but the direction of the effect will depend on the original characteristics of the soil (Woolf 2008). Tryon (1948) showed that charcoal increased the available moisture in sandy soil but had no effect in loamy soil and decreased the available moisture in clay soil. This suggests that charcoal addition may be ill-suited to clay soils. Conversely, an increase of available moisture observed in sandy soils may make biochar a useful tool in the reversal of desertification (Woolf 2008). Usowicz et al. (2016) described that biochar amendment to fallow land caused decreases in bulk density, particle density, thermal conductivity and thermal diffusivity. However, no significant effect of surface-applied biochar was observed on the soil thermal conductivity and thermal diffusivity under grassland. Moreover, biochar application to agricultural soils can change the surface albedo, which can counteract the climatemitigating potential of biochar (Usowicz et al. 2016). If there is greater albedo, then less UV will be absorbed by the soil (Kuppusamy et al. 2016). Biochar amendments caused reductions of albedo under both grassland and fallow land (Usowicz et al. 2016).

\subsection{Inorganic and organic contaminates in soil}

Numerous studies have proven that biochar increases the ability of soil to adsorb heavy metals and other contaminants, which is important for environmental protection and management (Tomczyk et al. 2019; Wei et al. 2018). Biochars have a carbonized and a non-carbonized fraction, which may interact with soil contaminants through oxygen-containing carboxyl, phenolic, hydroxyl and lactonic surface functional groups (Ahmad et al. 2014a). These fractions can play different roles in the adsorption process (Cao et al. 2009). The carbonized fraction is similar to the "glassy" fraction (analogous to glassy polymers), and the non-carbonized fraction is similar to the "soft" fraction (analogous to rubbery polymers) (Xia and Ball 1999). Biochar can be considered as a soil amendment that reduces the biotoxicity of pollutants (Cha et al. 2016; Li et al. 2017; Wang et al. 2019).

The effectiveness of contamination removal depends on the biochars specific surface area and cation exchange capacity (Ahmad et al. 2014b; Kołodyńska et al. 2012; Touray et al. 2014), as well as on the kind of interfering ions (Bogusz et al. 2015), $\mathrm{pH}$ of the solution, the dosage of biochar applied (Kılıç et al. 2013; Tomczyk et al. 2019), soil type, soil pH, contact time, metal concentration and temperature (Bradl 2004; Dube et al. 2001; Srivastava et al. 2005) as well as biochar type. Many studies have investigated heavy metal adsorption by biochars, including the adsorption of copper ions from water by a soil:biochar mixture at different $\mathrm{pH}$ values (Tomczyk et al. 2019), adsorption of heavy metal ions on kaolin (Srivastava et al. 2005), adsorption of zinc, copper and lead on zeolite (Perić et al. 2004), adsorption of platinum (IV) ions in loess soil (Bojanowska and Jackowska 2005), and the adsorption of heavy metal ions on biochars (Kołodyńska et al. 2012). All of the above studies were aimed at understanding how heavy metal ions are adsorbed from the liquid phase to the surface of the adsorbent and how the presence of biochar influences this process in soil (Liu et al. 2014). Colloids and organic ligands (Kerndorf and Schintzer 1980; Lion et al. 1982) as well as inorganic ones (Srivastava et al. 2005) have an influence on the adsorption process. Cao et al. (2009) investigated the sorption capacities of dairy manure biochar produced at low temperatures $\left(200{ }^{\circ} \mathrm{C}\right.$ and $\left.350{ }^{\circ} \mathrm{C}\right)$ and found that the biochar was six times more effective in removing lead $(\mathrm{Pb})$ from wastewater than a commercial activated carbon. Tong et al. (2011) investigated the copper adsorption capacity of three different biochars obtained by the pyrolysis of nut straw, soy and rapeseed. They found that the highest adsorptive 
capacity was exhibited by the biochar obtained from nut straw, then from soybeans, and then from rapeseed. They proved that the copper adsorption occurs through the formation of complexes with surface groups, specifically $-\mathrm{COOH}$ and phenolic groups (Tong et al. 2011). However, Karami et al. (2011) reported that the addition of oak biochar (in the amount of $20.0 \%(\mathrm{v} / \mathrm{v}))$ to soil reduced $\mathrm{Cu}$ sorption by approx. 69.0\%. Xu and Zhao (2013) showed that biochar from straws and peanut (in the amounts of 3.0 and $5.0 \%(\mathrm{v} / \mathrm{v}))$ increased the $\mathrm{Cu}$ sorption capacities of Oxisol, Utisol and Ultestinated soils, whereas biochar from rice reduced $\mathrm{Cu}$ in Ultisol derived from Quaternary red earth at the same doses (Jiang et al. 2012). However, woody biochar increased $\mathrm{Cu}$ adsorption onto Haplic Podzol at pH 3.0 and 5.0, with the most considerable changes observed at $\mathrm{pH} 5.0$ (increase in adsorption of 23.5\%) (Tomczyk et al. 2019).

Biochar may also adsorb other contaminants, such as PAH, antibiotics, and pesticides (Mui et al. 2010; $\mathrm{Xu}$ et al. 2011). For example, Chen and Yuan (2011) investigated the effect of biochars (obtained from pine needles at different temperatures) on the sorption of the PAHs naphtalene and phenantrene in soil. Biochar produced at high pyrolysis temperatures (400 and $700{ }^{\circ} \mathrm{C}$ ) demonstrated higher efficiency in the sorption affinity of biochar-soil than biochar obtained at low pyrolysis temperatures $\left(100\right.$ and $\left.300^{\circ} \mathrm{C}\right)$. Phenanthrene sorption of above $99.0 \%$ was controlled by biochar produced at 300 and $400{ }^{\circ} \mathrm{C}$ when present at $5.0 \%$. When the biochar content was only $0.5 \%$ for biochar $300{ }^{\circ} \mathrm{C}$ and $0.1 \%$ for biochar $400{ }^{\circ} \mathrm{C}$, the relative contributions of biochar and soil to total phenanthrene sorption were similar, but when the biochar content was increased to $5.0 \%$, phenanthrene sorption of $90.0 \%$ and $98.0 \%$ was contributed by biochar produced at 300 and $400{ }^{\circ} \mathrm{C}$, respectively (Chen and Yuan 2011). With the addition of 5.0\% biochar at $100{ }^{\circ} \mathrm{C}, 5.0 \%$ biochar at $300{ }^{\circ} \mathrm{C}, 5 \%$ biochar at $400{ }^{\circ} \mathrm{C}$, and $2.0 \%$ biochar at $700{ }^{\circ} \mathrm{C}$, sorption of phenanthrene was enhanced by $1.8-3.4$ times, 5.1-10.4 times, 23.0-70.6 times, and 43.7-85.5 times in comparison with unamended soil (Chen and Yuan 2011). A similar phenomenon was observed for naphthalene sorption; the enhanced intensities were 1.7-3.2 times, 28.3-113.0 times, 58.6-314.0 times, and 138.0-1170.0 times the sorption of amended soil with a $5.0 \%$ series of biochar produced at 100, 300, 400 , and $700{ }^{\circ} \mathrm{C}$, respectively. The biochar dominated the overall sorption of naphtalene when added to the soil at a proportion of at least $0.5 \%$ for the biochar produced at $300{ }^{\circ} \mathrm{C}$ content and $0.1 \%$ for the biochar produced at $400{ }^{\circ} \mathrm{C}$ (Chen and Yuan 2011). Overall, for biochar-soils with the same biochar content, the saturated adsorption capacity of a sorbent estimated from the high concentration data values for PAHs increased with the biochar pyrolysis temperature in the order of $100<300<400<700{ }^{\circ} \mathrm{C}$ (Chen and Chen 2009; Chen and Yuan 2011). Li et al. (2019) investigated the sorption of sulfadiazine and tetracycline on wood biochar obtained at $600-800{ }^{\circ} \mathrm{C}$. The authors analysed the effects of porosity of biochar, size of antibiotic molecules and $\mathrm{pH}$ on the sorption process. It was found that the production of biochar at a higher temperature improved its mesoporosity (from 34.3 to $124.0 \mathrm{~m}^{2} / \mathrm{g}$ ) and its affinity for antibiotic sorption from the aquatic environment (from 6.42 to $163.0 \mathrm{mg}$ / $\mathrm{g}$ for tetracycline sorption and from 2.20 to $261.0 \mathrm{mg} /$ $\mathrm{g}$ for sulfadiazine sorption). The sorption efficiency of mesoporous biochar was associated with a higher internal porosity, which promoted the adsorption of smaller-size antibiotic molecules (Li et al. 2019). Additionally, desorption studies indicate irreversible adsorption of antibiotics, i.e., biochar adsorbs them permanently and they will probably not leach out in the soil (Li et al. 2019). Furthermore, Garcia-Perez (2008) found that biochars produced at temperatures above $700{ }^{\circ} \mathrm{C}$ are typically related to the production of PAHs, which are hazardous because of their carcinogenic and mutagenic properties, and low-temperature biochars (pyrolysed in the temperature range of $350-600{ }^{\circ} \mathrm{C}$ ) appear to carry fewer toxic inferences. Therefore, biochar that is produced as a soil fertility amendment needs to be specifically aimed at carbonizing the biomass material under moist conditions and at low temperatures (Novak et al. 2009).

\subsection{Biological properties of soils}

The pore system of biochar provides a safe habitat for soil microorganisms (i.e., mycorrhizal fungi, actinomycetes bacteria) (Compant et al. 2010). These microorganisms are food for protozoa, mites, nematodes and other soil biota (Briones 2014). Biochar helps maintain microbiological populations at a higher level and simultaneously reduces the greenhouse gas emissions of soil (Compant et al. 2010). Weyers and Spokas (2011) reported short-term negative effects 
and long-term null effects of biochar amendment on earthworm activity in soil. Biochar derived from rice residues was observed to have a negative effect on the earthworm population that was related to the increase in soil $\mathrm{pH}$ induced by the biochar (Haefele et al. 2011). Li et al. (2011) recommended that a wet biochar application to soil could help mitigate negative effects on earthworms by preventing desiccation. Also, a positive effect of biochar amendment has been observed in soil enzymatic activity, which is an indicator of higher soil quality (Mierzwa-Hersztek et al. 2016; Ouyang et al. 2014). Ameloot et al. (2013) and Mierzwa-Hersztek et al. (2016) showed that biochar amendment caused an increase in the activity of dehydrogenase and urease in soil. Dehydrogenase activity increased by $19.0 \%$ and urease activity by 44.0\% (Mierzwa-Hersztek et al. 2016). Moreover, Mierzwa-Hersztek et al. (2016) reported that the addition of biochar to soil reduced soil acidity and increased the content of nitrogen and organic carbon.

\section{Conclusions}

This paper provides a review of the effects of temperature and type of feedstock on the physicochemical properties of biochar and its potential use as a soil conditioner.

The physicochemical properties $(\mathrm{pH}$, specific surface area, pore size, CEC, volatile mater, ash and carbon content) of biochar change with pyrolysis temperature and feedstock kind. Studies show that CEC and volatile matter decreased with increasing pyrolysis temperature, whereas $\mathrm{pH}$, specific surface area, ash and carbon content, pore volume increased with the increase in pyrolysis temperature. Increasing temperature also decreased the number of acidic functional groups, especially carboxylic functional groups, and caused appearance of basic functional groups. Biochar produced at high temperatures $\left(600-700{ }^{\circ} \mathrm{C}\right)$ exhibits a highly aromatic nature with well-organized $\mathrm{C}$ layers. This is most likely due to the degree of organic matter decomposition and the formation of micropores. In addition, this set of physicochemical properties is also a consequence of destruction of aliphatic alkyls and ester groups as well as the exposure of the aromatic lignin cores to high pyrolysis temperatures.
The moisture, as well as lignin and cellulose content in biomass have considerable influence on biochar formation. These can be attributed to the presence of different organic constituents in feedstock. Lignin is amorphous and hydrophobic polymer with high molecular weight and numerous functional groups of aromatic substructure. Cellulose and hemicelluloses are consisting of simple sugar monomer, which decompose at a temperature lower than $450{ }^{\circ} \mathrm{C}$. Cellulose present in the biomass helps in the formation of tar, while high lignin content is favourable for char production. Biochars produced from animal litter and solid waste feedstocks exhibit lower surface areas, carbon content, volatile matter and high CEC as compared to biochars produced from crop residue and wood biomass, even at higher pyrolysis temperatures. Biochar derived from manures, sewage sludge or crop residues show higher potential as nutrient source or inorganic sorbent. Wood-biochar possesses considerable merit for the improvement: (1) organic pollutants removal (antibiotics, pesticides), (2) carbon sequestration and (3) soil $\mathrm{pH}$, due to the high carbon and ash content, as well as high specific surface area, volatile matter and alkaline $\mathrm{pH}$.

Biochar reveals the potential to contribute to resolving economic, public health and environmental problems that are widespread and need to be overcome. In summary, more research is needed regarding biochar technology, suitability and sustainability as a soil fertilizer or decontaminator.

Acknowledgements Research was partially conducted under the project "Water in soil - satellite monitoring and improving the retention using biochar" No. BIOSTRATEG3/345940/7/NCBR/ 2017 which was financed by Polish National Centre for Research and Development in the framework of "Environment, agriculture and forestry" - BIOSTRATEG strategic R\&D programme

Open Access This article is licensed under a Creative Commons Attribution 4.0 International License, which permits use, sharing, adaptation, distribution and reproduction in any medium or format, as long as you give appropriate credit to the original author(s) and the source, provide a link to the Creative Commons licence, and indicate if changes were made. The images or other third party material in this article are included in the article's Creative Commons licence, unless indicated otherwise in a credit line to the material. If material is not included in the article's Creative Commons licence and your intended use is not permitted by statutory regulation or exceeds the permitted use, you will need to obtain permission directly from the copyright holder. To view a copy of this licence, visit http://creativecommons.org/licenses/by/4.0/. 


\section{References}

Abdulaha-Al Baquy M, Li J-Y, Xu C-Y, Mehmood K, Xu R-K (2017) Determination of critical $\mathrm{pH}$ and $\mathrm{Al}$ concentration of acidic Ultisols for wheat and canola crops. Solid Earth 8:149-159

Ahmad M, Lee SS, Dou X, Mohan D, Sung JK, Yang JE, Ok YS (2012) Effects of pyrolysis temperature on soybean stoverand peanut shell-derived biochar properties and TCE adsorption in water. Bioresour Technol 118:536-544

Ahmad M, Lee SS, Lim JE, Lee SE, Cho JS, Moon DH, Hashimoto Y, Ok YS (2014a) Speciation and phytoavailability of lead and antimony in a small arms range soil amended with mussel shell, cow bone and biochar: EXAFS spectroscopy and chemical extractions. Chemosphere 95:433-441

Ahmad M, Rajapaksha AU, Lim JE, Zhang M, Bolan N, Mohan D, Withanage M, Lee SS, Ok YS (2014b) Biochar as a sorbent for contaminant management in soil and water: a review. Chemosphere 99:19-33

Alburquerque JA, Calero JM, Barrón V, Torrent J, del Campillo MC, Gallardo A, Villar R (2014) Effects of biochars produced from different feedstocks on soil properties and sunflower growth. J Plant Nutr Soil Sci 177:16-25

Al-Wabel MI, Al-Omran E, El-Naggar AH, Nadeem M, Usman AR (2013) Pyrolysis temperature induced changes in characteristic and chemical composition of biochar produced from conocarpus wastes. Bioresour Technol 131:374-379

Ameloot N, De Neve S, Jegajeevagan K, Yildiz G, Buchan D, Funkuin YN, Prins W, Bouckaert L, Sleutel S (2013) Shortterm $\mathrm{CO}_{2}$ and $\mathrm{N}_{2} \mathrm{O}$ emissions and microbial properties of biochar amended sandy loam soils. Soil Biol Biochem 57:401-410

Amonette JE, Joseph S (2009) Charecteristics of biochar: microchemical properties. In: Lehmann J, Joseph S (eds) Biochar for environmental management science and technology. Earthscan, London

Anawar HM, Akter F, Solaiman ZM, Strezov V (2015) Biochar: and emerging panacea for remediation of soil contaminants from mining, industry and sewage wastes. Pedosphere 25:654-665

Antal MJ, Grønli M (2003) The art, science, and technology of charcoal production. Ind Eng Chem Res 42:1619-1640

Apaydın-Varol E, Pütün AE (2012) Preparation and characterization of pyrolytic chars from different biomass sample. J Anal Appl Pyrol 98:29-36

Asadullah M, Rahman MA, Ali MM, Rahman MS, Motin MA, Sultan MB, Alam MR (2007) Production of bio-oil from fixed bed pyrolysis of bagasse. Fuel 86:2514-2520

Baghdadi N, Zribi M (2016) Characterization of soil surface properties using radar remote sensing. In: Baghdadi N, Zribi M (eds) Land surface remote sensing in continental hydrology. Elsevier, Oxford, pp 1-39

Banik C, Lawrinenko M, Bakshi S, Laird DA (2018) Impact of pyrolysis temperature and feedstock on surface charge and functional group chemistry of biochars. J Environ Qual 47:452-461

Blanco-Canqui H (2017) Biochar and soil physical properties. Soil Sci Soc Am J 81:687-711
Bogusz A, Oleszczuk P, Dobrowolski R (2015) Application of laboratory prepared and commercially available biochars to adsorption of cadmium, copper and zinc ions from water. Bioresour Technol 196:540-549

Bojanowska M, Jackowska I (2005) Sorpcja jonów platyny (IV) w glebie lessowej. Roczniki Gleboznawcze Tom LVI nr. 1/2, Warszawa 2005, pp 5-12 (in Polish)

Bonelli PR, Buonomo EL, Cukierman AL (2007) Pyrolysis of sugarcane bagasse and co-pyrolysis with an argentinean subbituminous coal. Energy Sour Part A 29:731-740

Bourke J, Manley-Harris M, Fushimi C, Dowaki K, Nunoura T, Antal MJ (2007) Do all carbonized charcoals have the same chemical structure? 2. A model of the chemical structure of carbonized charcoal. Ind Eng Chem Res 46:5954-5967

Bradl HB (2004) Adsorption of heavy metal ions on soils and soils constituents. J Colloid Interface Sci 277(1):1-18

Brewer CE (2012) Biochar characterization and enigneering. Paper 12284, Iowa State University

Briones MIJ (2014) Soil fauna and soil functions: a jigsaw puzzle. Fron Environ Sci. https://doi.org/10.3389/fenvs. 2014.00007

Cabeza I, Waterhouse T, Sohi S, Rooke JA (2018) Effect of biochar produced from different biomass sources and at different process temperatures on methane production and ammonia concentrations in vitro. Anim Feed Sci Technol 237:1-7

Cantrell KB, Hunt PG, Uchimiya M, Novak JM, Ro KS (2012) Impact of pyrolysis temperature and manure source on physicochemical characteristics of biochar. Bioresour Technol 107:419-428

Cao X, Harris W (2010) Properties of dairy-manure-derived biochar pertinent to its potential use in remediation. Bioresour Technol 101:5222-5228

Cao X, Ma L, Gao B, Harris W (2009) Dairy-manure derived biochar effectively sorbs lead and atrazine. Environ Sci Technol 49(9):3285-3291

Cárdenas-Aguiar E, Gascó G, Paz-Ferreiro J, Méndez A (2017) the effect of biochar and compost from urban organic waste on plant biomass and properties of an artificially copper polluted soil. Int Biodeterior Biodegrad 124:223-232

Carrier M, Hardie AG, Uras U, Görgens J, Knoetze J (2012) Production of char from vacuum pyrolysis of South-African sugar cane bagasse and its characterization as activated carbon and biochar. J Anal Appl Pyrolysis 96:24-32

Cely P, Gascó G, Paz-Ferreiro J, Méndez A (2015) Agronomic properties of biochars from different manure wastes. J Anal Appl Pyrol 111:173-182

Cha J, Park SH, Jung S-C, Ryu C, Jeon J-K, Shin M-C, Park Y-K (2016) Production and utilization of biochar: a review. J Ind Eng Chem 40:1-15

Chan KY, Van Zwieten L, Meszaros I, Downie A, Joseph S (2007) Agronomic values of greenwaste biochar as a soil amendment. Aust J Soil Res 45:629-634

Cheah S, Jablonski WS, Olstad JL, Carpenter DL, Barthelemy KD, Robichaud DJ, Andrews JC, Black SK, Oddo MD, Westover TL (2016) Effects of thermal pretreatment and catalyst on biomass gasification efficiency and syngas composition. Green Chem 18:6291-6304

Chen B, Chen Z (2009) Sorption of naphthalene and 1-naphthol by biochars of orange peels with different pyrolytic temperatures. Chemosphere 76:127-133 
Chen B, Yuan M (2011) Enhanced sorption of polycyclic aromatic hydrocarbons by soil amended with biochar. J Soil Sediment 11:62-71

Chen BL, Zhou D, Zhu L (2008) Transitional adsorption and partition of nonpolar and polar aromatic contaminants by biochars of pine needles with different pyrolytic temperatures. Environ Sci Technol 42:5137-5143

Chen X, Chen G, Chen L, Chen Y, Lehmann J, McBride MB, Hay AG (2011) Adsorption of copper and zinc by biochars produced from pyrolysis of hardwood and corn straw in aqueous solution. Bioresour Technol 102:8877-8884

Chen Y, Yang H, Wang X, Zhang S, Chen H (2012) Biomassbased pyrolytic polygeneration system on cotton stalk pyrolysis: influence of temperature. Bioresour Technol 107:419-428

Chen T, Zhang Y, Wang H, Lu W, Zhou Z, Zhang Y, Ren L (2014) Influence of pyrolysis temperature on characteristics and heavy metal adsorptive performance of biochar derived from municipal sewage sludge. Bioresour Technol 164:47-54

Chen T, Zhang Y, Wang H, Lu W, Zhou Z, Zhang Y, Ren L (2015) Influence of pyrolysis temperature on characteristic and heavy metal adsorptive performance of biochar derived from municipal sewage sludge. Bioresour Technol $164: 47-54$

Cheng CH, Lehmann J, Thies JE, Burton SD (2008) Stability of black carbon in soil across a climatic gradient. J Geophys Res 113:1-10

Chun Y, Sheng GY, Chiou CT, Xing BS (2004) Compositions and sorptive properties of crop residue-derived chars. Environ Sci Technol 38:4649-4655

Claoston N, Samsuri AW, Ahmad Husni MH, Mohd Amran MS (2014) Effects of pyrolysis temperature on the physicochemical properties of empty fruit bunch and rice husk biochars. Waste Manag Res 32:331-339

Compant S, Clément S, Sessitsch A (2010) Plant growth-promoting bacteria in the rhizo- and endosphere of plants: their role, colonization, mechanisms involved and prospects for utilization. Soil Biol Biochem 42:669-678

Crombie K, Mašek O, Sohi SP, Brownsort P, Cross A (2013) The effect of pyrolysis conditions on biochar stability as determined by three methods. Glob Chang Biol Bioenergy 5:122-131

Cybulak M, Sokołowska Z, Boguta P (2016) Hygroscopic moisture content of podzolic soil with biochar. Acta Agroph 23(4):533-543

Daful AG, Chandraratne MR (2018) Biochar production from biomass waste-derived material. Reference module in materials science and materials engineering. Elsevier, Amsterdam, pp 11249-11258

Darmstadt H, Pantea D, Sümmchen L, Roland U, Kaliaguine S, Roy C (2000) Surface and bulk chemistry of charcoal obtained by vacuum pyrolysis of bark: influence of feedstock moisture content. J Anal Appl Pyrol 53:1-17

de la Rosa JM, Paneque M, Miller AZ, Knicker H (2014) Relating physical and chemical properties of four different biochars and their application rate to biomass production of Lolium perenne on a Calcic Cambisol during a pot experiment of 79 days. Sci Total Environ 499:175-184

Deenik JL, McClellan T, Uehara G, Antal MJ, Campbell S (2010) Charcoal volatile matter influences plant growth and soil nitrogen transformations. Soil Sci Soc Am J 74:1259-1270

Demirbas A (2004) Effects of temperature and particle size on bio-char yield from pyrolysis of agricultural residues. J Anal Appl Pyrol 72:243-248

Denyes MJ, Parisien MA, Rutter A, Zeeb BA (2014) Physical, chemical and biological characterization of six biochar produced for the remediation of contamined soils. J Vis Exp 93:52183

Ding W, Dong X, Ime IM, Gao B, Ma LQ (2014) Pyrolytic temperatures impact lead sorption mechanisms by bagasse biochars. Chemosphere 105:68-74

Ding Y, Liu Y, Liu S, Li Z, Tan X, Huang X, Zeng G, Zhou L, Zheng B (2016) Biochar to improve soil fertility: a review. Agron Sustain Dev 36:36

Domingues RR, Trugilho PF, Silva CA, de Melo ICNA, Melo LCA, Magriotis ZM, Sánchez-Monedero MA (2017) Properties of biochar derived from wood and high-nutrient biomasses with the aim of agronomic and environmental benefits. PLoS ONE 12:e0176884

Dube A, Zbytniewski R, Kowalkowski T, Cukrowska E, Buszewski B (2001) Adsorption and Migration of Heavy Metals in Soil. Pol J Environ Stud 10(1):1-10

Duong VT, Khanh NM, Nguyen NH, Phi NN, Nquyen T-C, Xo DH (2017) Impact of biochar on the water holding capacity and moisture of basalt and grey soil. J Sci Ho Chi Minh City Open Univers 7:36-43

Elaigwu SE, Rocher V, Kyriakou G, Greenway G (2014) Removal of $\mathrm{Pb}^{2+}$ and $\mathrm{Cd}^{2+}$ from aqueous solution using chars from pyrolysis and microwave-assisted hydrothermal carbonization of Prosopis Africana shell. J Ind Eng Chem 20:3467-3473

El-Gamal E, Saleh M, Elsokkary I, Rashad M, Abd El-Latif MM (2017) Comparison between properties of biochar produced by traditional and controlled pyrolysis. J Alex Sci Exch 38:413-424

Enders A, Hanley K, Whitman T, Joseph S, Lehmann J (2012) Characterization of biochars to evaluate recalcitrance and agronomic performance. Bioresour Technol 114:644-653

Fernandes MB, Brooks P (2003) Characterization of carbonaceous combustion residues: II. Nonpolar organic compounds. Chemosphere 53:447-458

Fuertes AB, Camps Arbestain M, Sevilla M, Maciá-Agulló JA, Fiol S, López R, Smernik RJ, Aitkenhead WP, Arce F, Macias F (2010) Chemical and structural properties of carbonaceous products obtained by pyrolysis and hydrothermal carbonisation of corn stover. Aust J Soil Res 48:618-626

Garcia-Jaramillo M, Cox L, Knicker HE, Cornejo J, Spokas KA, Hermosín MC (2015) Characterization and selection of biochar for an efficient retention of tricyclazole in a flooded alluvial paddy soil. J Hazard Mater 286:581-588

Garcia-Perez M (2008) The formation of polyaromatic hydrocarbons and dioxins during pyrolysis: a review of the literature with descriptions of biomass composition. Fast Pyrolysis Technologies and Thermochemical Reactions. Washington State University, Pullman

Gąsior D, Tic WJ (2017) Application of the biochar-based technologies as the way of realization of the sustainable development strategy. Econ Environ Stud 17:597-611 
Gaskin JW, Steiner C, Harris K, Das KC, Bibens B (2008) Effect of low- temperature pyrolysis conditions on biochar for agricultural use. Trans Asabe 51(6):2061-2069

Gerlach H (2014) Biochar in poultry farming. The Biochar Journal, Arbaz, Switzerland, www.biocharjournal.org/en/ $\mathrm{ct} / 10$

Ghani WAWAK, Mohd A, de Silva G, Bachmann RT, TaufiqYap YH, Rashid U, Al-Muhtaseb AH (2013) Biochar production from waste rubber-wood-sawdust and its potential use in $\mathrm{C}$ sequestration: chemical and physical characterization. Ind Crop Prod 44:18-24

Glaser B, Lehmann J, Zech W (2002) Ameliorating physical and chemical properties of highly weathered soils in the tropics with charcoal: a review. Springer, Berlin

Głuszek S, Sas-Paszt L, Sumorok B, Kozera R (2017) Biocharrhizosphere interactions-a review. Pol J Microbiol 66:151-161

Gomez-Eyles J, Beesley L, Moreno-Jiménez E, Ghosh U, Sizmur T (2013) The potential of biochar amendments to remediate contaminated soils. In: Ladygina N, Rineau F (eds) Biochar and soil biota. CRC Press, Boca Raton

Guo M, Shen Y, He Z (2012) Poultry litter-based biochar: preparation, characterization, and utilization. In: He Z (ed) Applied research in animal manure management: challenges and opportunities beyond the adverse environmental impacts. Nova Science Publishers, Hauppauge, NY, pp 171-202

Haefele SM, Konboon Y, Wongboon W, Amarante S, Maarifat AA, Pfeiffer EM, Knoblauch C (2011) Effects and fate of biochar from rice residues in rice-based systems. Field Crop Res 121:430-440

Harris PJF (1997) Structure of non-graphitising carbons. Int Mater Rev 42(5):206-218

Harris PJF, Tsang SC (1997) High resolution of electron microscopy studies of non-graphitizing carbons. Philos Mag A 76(3):667-677

Hass A, Gonzalez JM, Lima I, Godwin HW, Halvorson JJ, Boyer DG (2012) Chicken manure biochar as liming and nutrient source fo acid appalachian soil. J Environ Qual 41:1096-1106

Hernandez-Mena LE, Pécora AAB, Beraldo AL (2014) Slow pyrolysis of bamboo biomass: analysis of biochar properties. Ital Assoc Chem Eng 37:115-120

Hernandez-Soriano MC, Kerré B, Kopittke PM, Horemans B, Smolders E (2016) Biochar affects carbon composition and stability in soil: a combined spectroscopy-microscopy study. Sci Rep 6:25127

Inyang M, Gao B, Pullammanappallil P, Ding W, Zimmerman AR (2010) Biochar from anaerobically digested sugarcane bagasse. Bioresour Technol 101:8868-8872

Jafri N, Wong WY, Doshi Y, Yoon LW, Cheah KH (2018) A review on production and characterization of biochars for application in direct carbon fuel cells. Process Saf Environ 118:152-166

Janus A, Pelfrêne A, Heymans S, Deboffe C, Douay F, Waterlot C (2015) Elaboration, characteristics and advantages of biochars for the management of contaminated soils with a specific overview on Miscanthus biochars. J Environ Manage 162:275-289

Jeba Jeevitha RS, Bella GR, Booshan SAT (2015) Preparation and characterization of micro crystalline cellulose fiber reinforced chitosan based polymer composites. Res Chem $8: 453-458$

Jha P, Biswas AK, Lakaria BL, Subba Rao A (2010) Biochar in agriculture-prospects and related implications. Curr Sci 99:1218-1225

Jiang J, Xu RK, Jiang TY, Li Z (2012) Immobilization of Cu(II), $\mathrm{Pb}(\mathrm{II})$ and $\mathrm{Cd}(\mathrm{II})$ by the addition of rice straw derived biochar in a simulating polluted Ultisol. J Hazard Mater 229-230:145-150

Jin Y, Liang X, He M, Liu Y, Tian G, Shi J (2016) Manure biochar influence upon soil properties, phosphorus distribution and phosphatase activites: a microcosm incubation study. Chemosphere 142:128-135

Jindo K, Mizumoto H, Sawada Y, Sanchez-Monedero MA, Sonoki T (2014) Physical and chemical characterization of biochars derived from different agricultural residues. Biogeosciences 11:6613-6621

Joseph SD, Camps-Arbestain M, Lin Y, Munroe P, Chia CH, Hook J, van Zwieten L, Kimber S, Cowie A, Singh BP, Lehmann J, Foidl N, Smernik RJ, Amonette JE (2010) An investigation into the reactions of biochar in soil. Aust $\mathrm{J}$ Soil Res 48:501-515

Kajina W, Rousset P (2018) Coupled effect of feedstock and pyrolysis temperature on biochar as a soil amendment. https://agritrop.cirad.fr/590896/

Karami N, Clemente R, Moreno-Jiménez E, Lepp NW, Beesley L (2011) Efiiciency of green waste compost and biochar soil amendments for reducing lead and copper mobility and uptake to ryegrass. J Hazard Mater 191:41-48

Karaosmanoglu F (2000) Biobriquetting of rapeseed cake. Energy Sources 22(3):257-267

Kardam A, Raj KR, Srivastava S (2012) Green nanotechnology for bioremediation of toxic metals from waste water. In: Khemani LD, Srivastava MM, Srivastava S (eds) Chemistry of phytopotentials: health, energy and environmental perspectives. Springer, Berlin, pp 373-377

Karunanithi R, Sik Ok Y, Dharmarajan R, Ahmad M, Seshadri B, Bolan N, Naidu R (2017) Sorption, kinetics and thermodynamics of phosphate sorption onto soybean stover derived biochar. Environ Technol Innov 8:113-125

Kasozi GN, Zimmerma AR, Nkedi-Kizza P, Gao B (2010) Catechol and humic acid sorption onto a range of laboratory-produced black carbons (biochars). Environ Sci Technol 44:6189-6195

Katyal S, Thambimuthu K, Valix M (2003) Carbonisation of bagasse in a fixed bed reactor: influence of process variables on char yield and characteristics. Renew Energy 28:713-725

Kawamoto HMM, Saka S (2003) Pyrolysis behavior of levoglucosan as an intermediate in cellulose pyrolysis: polymerization into polysaccharide as a key reaction to carbonized product formation. J Wood Sci 49:469-473

Keiluweit M, Nico PS, Johnson MG, Kleber M (2010) Dynamic molecular structure of plant-derived black carbon (biochar). Environ Sci Technol 44:1247-1253

Kerndorf H, Schintzer M (1980) Sorption of metals on humic acid. Geochim Cosmochim Acta 44:1701-1708

Kılıç M, Kırbıyık C, Çepelioğullar O, Pütün AE (2013) Adsorption of heavy metal ions from aqueous solutions by bio-char, a by-product of pyrolysis. Appl Surf Sci 283:856-862 
Kloss S, Zehetner F, Dellantonio A, Hamid R, Ottner F, Liedtke V, Schwanninger M, Gerzabek MH, Soja G (2012) Characterization of slow pyrolysis biochars: effects of feedstocks and pyrolysis temperature on biochar properties. J Environ Qual 41:990-1000

Kołodyńska D, Wnętrzak R, Leahy JJ, Kwapiński W, Hayes MHB, Hubicki Z (2012) Kinetic and adsorptive characterization of biochar in metal ions removal. Chem Eng $\mathrm{J}$ 197:295-305

Kookana RS, Sarmah AK, Van Zwieten L, Krull E, Singh B (2011) Biochar application to soil: agronomic and environmental benefits and unintended consequences. In: Donald LS (ed) Advances in agronomy 112. Academic Press, San Diego, pp 103-143

Kumar G, Shobana S, Chen WH, Bach QV, Kim S-H, Atabani AE, Chang J-S (2016) A review of thermochemical conversion of microalgal biomass for biofuels: chemistry and processes. Green Chem 19:46-47

Kuppusamy S, Thavamani P, Megharaj M, Venkateswarlu K, Naidu R (2016) Agronomic and remedial benefits and risks of applying biochar to soil: current knowledge and future research directions. Environ Int 87:1-12

Kutilek M, Jendele L, Panayiotopoulos K (2006) The influence of uniaxial compression upon pore size distribution in bimodal soils. Soil Tillage Res 86(1):27-37

Lee JW, Kidder M, Evans BR, Paik S, Buchanan AC, Garten C, Brown RC (2010) Characterization of biochars produced from cornstovers for soil amendment. Environ Sci Technol 44:7970-7974

Lee Y, Park J, Gang KS, Ryu C, Yang W, Jung J-H, Hyun S (2013a) Production and characterization of biochar from various biomass materials by slow pyrolysis. Tech Bull J Food Fertil Technol Center 197:1-11

Lee Y, Park J, Ryu C, Gang KS, Yang W, Park Y-K, Jung J, Hyun S (2013b) Comparison of biochar properties from biomass residues produced by slow pyrolysis at $500^{\circ} \mathrm{C}$. Bioresour Technol 148:196-201

Lee XJ, Lee LY, Gan S, Thangalazhy-Gopakumar S, Ng HK (2017) Biochar potential evaluation of palm oil wastes through slow pyrolysis: thermochemical characterization and pyrolytic kinetic studies. Bioresour Technol 236:155-163

Lehmann J, Joseph S (2009) Biochar for environmental management: an introduction. In: Lehmann J, Joseph S (eds) Biochar for environmental management: science and technology. Earthscan, London, pp 1-12

Lehmann J, Liang BQ, Solomon D, Lerotic M, Luizão F, Kinyangi J, Schäfer T, Wirick S, Jacobsen C (2005) Nearedge $\mathrm{x}$-ray absorption fine structure (NEXAFS) spectroscopy for mapping nano-scale distribution of organic carbon forms in soil: application to black carbon particles. Global Biogeochem Cycles 19:1013

Lehmann J, Gaunt J, Rondon M (2006) Bio-char sequestration in terrestrial ecosystems - a review. Mitig Adapt Strat Gle 11:403-427

Lehmann J, Rilig MC, Thies J, Masiello CA, Hockaday WC, Crowley D (2011) Biochar affects on soil biota—a review. Soil Biol Biochem 43:1812-1836

Lei O, Zhang R (2013) Effects of biochars derived from different feedstocks and pyrolysis temperatures on soil physical and hydraulic properties. J Soil Sediment 13:1561-1572

Lewandowski W, Radziemska M, Ryms E, Ostrowski P (2010) Nowoczesne metody termochemiczne konwersji biomasy w paliwa gazowe, ciekłe i stałe. Proceedings of ECOpole 4 (2) (in Polish)

Li D, Hockaday WC, Masiello CA, Alvarez PJJ (2011) Earthworim avoidance of biochar can be mitigated by wetting. Soil Biol Biochem 43:1732-1737

Li X, Shen Q, Zhang D, Mei X, Ran W, Xu Y, Yu G, Motta A (2013) Functional groups determine biochar properties (pH and EC) as studied by two-dimensional ${ }^{13} \mathrm{C}$ NMR correlation spectroscopy. PLoS ONE 8(6): 65949

Li H, Dong X, da Silva EB, de Oliveira LM, Chen Y, Ma LQ (2017) Mechanisms of metal sorption by biochars: biochar characteristics and modifications. Chemosphere 178:466-478

Li C, Zhu X, He H, Fang Y, Dong H, Lü J, Li J, Li Y (2019) Adsorption of two antibiotics on biochar prepared in aircontaining atmosphere: influence of biochar porosity and molecular size of antibiotics. J MolLiq 274:353-361

Lian F, Huang F, Chen W, Xing B, Zhu L (2011) Sorption of apolar and polar organic contaminants by waste tire rubber and its chars in single- and bi-solute systems. Environ Pollut 159:850-857

Liang B, Lehmann J, Solomon D, Kinyangi J, Grossman J, O'Neill B, Skjemstad JO, Thies J, Luizão FJ, Petersen J, Neves EG (2006) Black carbon increases cation exchange capacity in soils. Soil Sci Soc Am J 70:1719-1730

Liang B, Lehmann J, Sohi S, Thies JE, O’Neill B, Trujillo L, Gaunt J, Solomon D, Grossman J, Neves EG, Luizão FJ (2010) Black carbon affects the cycling of non-black carbon in soil. Org Geochem 41:206-213

Lion LW, Altmann RS, Leckie JO (1982) Trace metal adsorption characteristics of estuatrine particulate matter: evaluation of contributions of $\mathrm{Fe} / \mathrm{Mn}$ oxide and organic surface coatings. Environ Sci Technol 16:660-666

Liu T, Liu B, Zhang W (2014) Nutrients and heavy metals in biochar produced by sewage sludge pyrolysis: its application in soil amendment. Pol J Environ Stud 23:271-275

Liu Y, He Z, Uchimiya M (2015) Comparison of biochar formation from various agricultural by-products using FTIR spectroscopy. Mod Appl Sci 9:246-253

Lu H, Zhang W, Yang Y, Huang X, Wang S, Qiu R (2012) Relative distribution of $\mathrm{Pb} 2+$ sorption mechanisms by sludge-derived biochar. Water Res 46:854-862

Lupoi JS, Smith EA (2012) Characterization of woody and herbaceous biomasses lignin composition with $1064 \mathrm{~nm}$ dispersive multichannel Raman spectroscopy. Appl Spectrosc 66:903-910

Maguire RO, Agblevor FA (2010) Biochar in agricultural systems. Laboratory Procedures; Virginia Tech Soil Testing Laboratory. Virginia Cooperative Extension, Blacksburg, VA. Available at: http://pubs.ext.vt.edu/452/452-881/452881_pdf.pdf.

Malińska K (2012) Biowęgiel odpowiedzią na aktualne problem ochrony środowiska. Inżynieria i ochrona środowiska 15:387-403 (in Polish)

Mia S, Singh B, Dijkstra FA (2017) Aged biochar affects gross nitrogen mineralization and recovery; A $15 \mathrm{~N}$ study in two 
contrasting soils. Glob Change Biol Bioenergy 9:1196-1206

Mierzwa-Hersztek M, Gondek K, Baran A (2016) Effect of poultry litter biochar on soil enzymatic activity, ecotoxicity and plant growth. ApplSoil Ecol 105:144-150

Mitchell PJ, Dalley TSL, Helleur RJ (2013) Preliminary laboratory production and characterization of biochars from lignocellulosic municipal waste. J Anal Appl Pyrol 99:71-78

Mohan D, Pitman CU Jr, Steele PH (2006) Pyrolysis of wood/ biomass for bio-oil: a critical review. Energy Fuels 20:848-889

Mohan D, Rajput S, Singh VK, Steele PH, Pittman CU Jr (2011) Modeling and evaluation of chromium remediation from water using low cost bio-char, a green adsorbent. J Hazard Mater 188:319-333

Montes-Morán MA, Suárez D, Menéndez JA, Fuente E (2004) On the nature of basic sites on carbon surfaces: an overview. Carbon 42:1219-1225

Mui ELK, Cheung WH, Valix M, McKay G (2010) Dye adsorption onto char from bamboo. J Hazard Mater 177(1-3):1001-1005

Mukherjee A, Zimmerman AR, Harris W (2011) Surface chemistry variations among a series of laboratory-produced biochar. Geoderma 163:247-255

Mukome FND, Zhang X, Lucas CRS, Six J, Parikh SJ (2013) Use of chemical and physical characteristics to investigate trends in biochar feedstocks. J Agric Food Chem 61:2196-2204

Mullen CA, Boateng AA, Goldberg NM, Lima IM, Laird DA, Hicks KB (2010) Bio-oil and bio-char production from corn cobs and stover by pyrolysis. Biomass Bioenergy 34:67-74

Naga Raju M, Golla N, Vengatampalli R (2017) Soil physicochemical properties (chapter 2). In: Naga Raju M, Golla N, Vengatampalli R (eds) Soil enzymes: influence of sugar industry effluents on soil enzyme activities. Springer, Cham, pp 5-8

Nair VD, Ramachandran Nair PK, Dari B, Freitas AM, Chatterjee N, Pinheiro FM (2017) Biochar in the agroecosystem-climate-change-sustainability nexus. Front Plant Sci $8: 2051$

Ndriangu SM, Liu Y, Xu K, Song S (2019) Risk evaluation of pyrolyzed biocharfrom multiple wastes. J Chem, Article ID 4506314

Nguyen B, Lehmann J, Hockaday WC, Joseph S, Masiello CA (2010) Temperature sensitivity of black carbon decomposition and oxidation. Environ Sci Technol 44:3324-3331

Novak JM, Lima I, Xing B, Gaskin JW, Steiner C, Das KC, Ahmenda M, Rehrah D, Watts DW, Busscher WJ, Schomberg H (2009) Characterization of designer biochar produced at different temperatures and their effects on loamy sand. Ann Environ Sci 3:195-206

Novak J, Sigua G, Watts D, Cantrell K, Shumaker P, Szogi A, Johnson MG, Spokas K (2016) Biochars impact on water infiltration and water quality through a compacted subsoil layer. Chemosphere 142:160-167

Ouyang L, Tang Q, Yu L, Zhang R (2014) Effects of amendment of different biochars on soil enzyme activities related to carbon mineralisation. Soil Res 52(7):706-716
Özçimen D, Ersoy-Meriçboyu A (2010) Characterization of biochar and bio-oil samples obtained from carbonization of various biomass materials. Renew Energy 35:1319-1324

Parmar A, Nema PK, Agarwal T (2014) Biochar production from agrofood industry residues: a sustainable approach for soil and environmental management. Curr Sci 107(10):1673-1682

Paz-Ferreiro J, Nieto A, Méndez A, Askeland MPJ, Gascó G (2018) Biochar from Biosolids Pyrolysis: a Review. Int J Environ Res Public Health 15:956

Perić J, Trgo M, Vukojević Medvidović N (2004) Removal of zinc, copper and lead by natural zeolite-a comparison of adsorption isotherms. Wat Res 38:1893-1899

Pichtel J (2014) Waste management practices: municipal, hazardous, and industrial, 2nd edn. CRC Press, Boca Raton

Pretsch E, Bühlmann P, Badertscher M (2009) Structure determination of organic compounds. Springer, Berlin

Rafiq MK, Bachmann RT, Rafiq MT, Shang Z, Joseph S, Long R (2016) Influence of pyrolysis temperature on physicochemical properties of corn stover (Zea mays L) biochar and feasibility for carbon capture and energy balance. PLoS ONE 11:e0156894

Rauber D, Dier TKF, Volmer DA, Hempelmann R (2018) Electrochemical lignin degradation in ionic liquids on ternary mixed metal electrodes. Z Phys Chem 232:189-208

Raveendran K, Ganesh A (1998) Adsorption characteristic and pore-development of biomass pyrolysis char. Fuel 77:769-781

Revell KT, Maguire RO, Agblevor FA (2012) Influence of poultry litter biochar on soil properties and plant growth. Soil Sci 177(6):402-408

Ronsse F, van Hecke S, Dickinson D, Prins W (2012) Production and characterization of slow pyrolysis biochar: influence of feedstock type and pyrolysis conditions. Glob Chang Biol Bioenergy 5:104-115

Ruthiraan M, Abdullah EC, Kogiladas TR, Mujawar MN (2015) Synthesis of magnetic biochar from Garcinia Mangostana peel using muffle furnace for adsorption of $\mathrm{Zn} 2+$ ions from aqueous solution. Int J Chem Eng 2:18-21

Rutkowska B, Szulc W, Sosulski T, Stępień W (2014) Soil micronutrient availability to crops affected by long term inorganic and fertilizer applications. Plant Soil Environ 60:198-203

Saletnik B, Bajcar M, Zaguła G, Czernicka M, Puchalski C (2016) Impact of the biomass pyrolysis parameters on the quality of biocarbon obtained from rape straw, rye straw and willow chips. Econtechmod Int Q J 5:129-134

Schmidt MWI, Noack AG (2000) Black carbon in soils and sediments: analysis, distribution, implications, and current challenges. Global Biogeochem Cy 14:777-793

Shaaban A, Se S-M, Dimin MF, Juoi JM, Husin MH, Mitan NMM (2014) Influence of heating temperature and holding time on biochars derived from rubber wood sawdust via slow pyrolysis. J Anal Appl Pyrol 107:31-39

Shakya A, Agarwal T (2017) Poultry litter biochar: an approach towards poultry litter management-a review. Int J Curr Microbiol App Sci 6:2657-2668

Shariff A, Aziz NSM, Saleh NM, Ruzali NSI (2016) The effect of feedstock type and slow pyrolysis temperature on biochar yield from coconut wastes. Int Sch Sci Res Innov 10:1410-1414 
Sharma RK, Wooten JB, Baliga VL, Lin X, Chan WG, Hajaligol MR (2004) Characterization of chars from pyrolysis of lignin. Fuel 83:1469-1482

Shinogi Y, Kanri Y (2003) Pyrolysis of plant, animal and human waste: physical and chemical characterization of the pyrolytic products. Bioresour Technol 90:241-247

Singh BP, Cowie AL (2010) Characterisation and evaluation of biochars for their application as a soil amendment. Aust J Soil Res 48:516-525

Singh BP, Cowie AL, Smernik RJ (2012) Biochar carbon stability in a clayey soil as a function of feedstock and pyrolysis temperature. Environ Sci Technol 46:11770-11778

Sohi S, Krull E, Lopez-Capel E, Bol R (2010) A review of biochar and its use and function in soil. Adv Agron 105:47-82

Sombroek WG, Nachtergaele FO, Hebel A (1993) Amounts, dynamics and sequestering of carbon in tropical and subtropical soils. Ambio 22:417-426

Song W, Guo M (2012) Quality variations of poultry litter biochar generated at different pyrolysis temperatures. J Anal Appl Pyrol 94:138-145

Sopeña F, Semple K, Sohi S, Bending G (2012) Assessing the chemical and biological accessibility of the herbicide isoproturon in soil amended with biochar. Chemosphere 88:77-83

Spokas KA, Cantrell KB, Novak JM, Archer DW, Ippolito JA, Collins HP, Boateng AA, Lima IM, Lamb MC, McAloon AJ, Lentz RD, Nichols KA (2012) Biochar: a synthesis of its agronomic impact beyond carbon sequestration. J Environ Qual 41:973-989

Srivastava P, Singh B, Angove M (2005) Competitive adsorption behavior of heavy metals on kaolinite. J Colloid Inter Sci 290:28-38

Steinbeiss S, Gleixner G, Antonietti M (2009) Effect of biochar amendment on soil carbon balance and soil microbial activity. Soil Biol Biochem 41:1301-1310

Suliman W, Harsh JB, Abu-Lail NI, Fortuna A-M, Dallmeyer I, Garcia-Perez M (2016) Influence of feedstock source and pyrolysis temperature on biochar bulk and surface properties. Biomass Bioenergy 84:37-48

Sun Y, Gao B, Yao Y, Fang J, Zhang M, Zhou Y, Chen H, Yang L (2014) Effects of feedstock type, production method, and pyrolysis temperature on biochar and hydrochar properties. Chem Eng J 240:574-578

Sun X, Han X, Ping F, Zhang L, Zhang K, Chen M, Wu W (2018) Effect of rice-straw biochar on nitrous oxide emissions from paddy soils under elevated $\mathrm{CO}_{2}$ temperature. Sci Total Environ 628-629:1009-1016

Tag AT, Duman G, Ucar S, Yanik J (2016) Effects of feedstock type and pyrolysis temperature on potential applications of biochar. J Anal Appl Pyrol 120:200-206

Thies JE, Rillig MC (2009) Characteristics of biochar: biological properties (Ch. 6). In: Lehmann J, Joseph S (eds) Biochar for Environmental Management. Earthscan, Gateshead, pp 85-105

Tomczyk A, Boguta P, Sokołowska Z (2019) Biochar efficiency in copper removal from Haplic soils. Int J Environ Sci Technol. https://doi.org/10.1007/s13762-019-02227-4
Tong X-J, Li I-Y, Yuan J-H, Xu R-K (2011) Adsorption of $\mathrm{Cu}$ (II) by biochars generated from three crop straws. Chem Eng J 172:828-834

Touray N, Tsai W-T, Chen H-R, Liu S-C (2014) Thermochemical and pore properties of goat-manure-derived biochars prepared from different pyrolysis temperatures. J Anal Appl Pyrol 109:116-122

Tripathi M, Sahu JN, Ganesan P (2016) Effect of process parameters on production of biochar from biomass waste through pyrolysis: a review. Renew Sust Energ Rev 55:467-481

Tryon EH (1948) Effect of charcoal on certain physical, chemical, and biological properties of forest soils. Ecol Monogr 18:81-115

Uchimiya M, Wartelle LH, Lima IM, Klasson KT (2010) Sorption of deisopropylatrazine on broiler litter biochars. J Agric Food Chem 58:12350-12356

Uchimiya M, Chang S, Klasson KT (2011a) Screening biochars for heavy metal retention in soil: role of oxygen functional groups. J Hazard Mater 190:432-441

Uchimiya M, Wartelle LH, Klasson KT, Fortier CA, Lima IM (2011b) Influence of pyrolysis temperature on biochar property and function as a heavy metal sorbent in soil. J Agric Food Chem 59:2501-2510

Uras Ü, Carrier M, Hardie AG, Knoetze JH (2012) Physicochemical characterization of biochars from vacuum pyrolysis of South African agricultural wastes for application as soil amendments. J Anal Appl Pyrol 98:207-213

Usowicz B, Lipiec J, Łukowski M, Marczewski W, Usowicz J (2016) The effect of biochar application on thermal properties and albedo of loess soil under grassland and fallow. Soil Till Res 164:45-51

Vamvuka D, Sfakiotakis S (2011) Effects of heating rate and water leaching of perennial energy crops on pyrolysis characteristic and kinetics. Renew Energy 36:2433-2439

Van Zwieten LV, Singh B, Joseph S, Kimber S, Cowei A, Chan KY (2009) Biochar and emissions of non-CO2 greenhouse gases from soil. In: Lehmann J, Joseph S (eds) Biochar for environmental management science and technology. Earthscans, UK, pp 227-250

Van Zwieten LV, Kimber S, Morris S, Chan KY, Downie A, Rust J, Joseph S, Cowie A (2010) Effects of biochar from slow pyrolysis of papermill waste on agronomic performance and soil fertility. Plan Soil 327:235-246

Vassilev SV, Baxter D, Andersen LK, Vassileva CG (2013) An overview of the composition and application of biomass ash. Part 1. Phase-mineral and chemical composition and classification. Fuel 105:40-76

Venegas A, Rigol A, Vidal M (2015) Viability of organic wastes and biochars as amendments for the remediation of heavy metal-contaminated soils. Chemosphere 119:190-198

Verheijen F, Jeffery S, Bastos AC, van der Velde M, Diafas I (2010) Biochar application to soils: a critical scientific review of effects on soil properties, processes and functions. EUR 24099 EN, Office for the Official Publications of the European Communities, Luxembourg

Wang S, Gao B, Zimmerman AR, Li Y, Ma L, Harris WG, Migliaccio KW (2015) Physicochemical and sorptive properties of biochars derived from woody and herbaceous biomass. Chemosphere 134:257-262 
Wang L, Wang Y, Ma F, Tankpa V, Bai S, Guo X, Wang X (2019) Mechanisms and reutilization of modified biochar used for removal of heavy metals from wastewater: a review. Sci Total Environ 668:1298-1309

Weber K, Quicker P (2018) Properties of biochar. Fuel 217:240-261

Wei D, Li B, Huang H, Luo L, Zhang J, Yang Y, Guo J, Tang L, Zeng G, Zhou Y (2018) Biochar-based functional materials in the purification of agricultural wastewater: fabrication, application and future research needs. Chemosphere 197:165-180

Weyers SL, Spokas KA (2011) Impact of biochar on earthworm populations: a review. Appl Environ Soil Sci 2011:1-12

Woolf D (2008) Biochar as a soil amendment: a review of the environmental implications. Swansea University, School of the Environment and Society. http://orgprints.org/13268

Woolf D, Amonette JE, Street-Perrott FA, Lehmann J, Joseph S (2010) Sustainable biochar to mitigate climate change. Nat Commun 1:1-56

Wu W, Yang M, Feng Q, McGrouther K, Wang H, Lu H, Chen Y (2012) Chemical characterization of rice straw-derived biochar for soil amendment. Biomass Bioenerg 47:268-276

Xia G, Ball WP (1999) Adsorption-partitioning uptake of nine low-polarity organic chemicals on a natural sorbent. Environ Sci Technol 33(2):262-269

Xie T, Sadasivam BY, Reddy KR, Wang C, Spokas K (2015) Review of the effects of biochar amendment on soil properties and carbon sequestration. J Hazard Toxic Radioact Waste 20:04015013

Xu R-K, Zhao A-Z (2013) Effect of biochars on adsorption of $\mathrm{Cu}(\mathrm{II}), \mathrm{Pb}$ (II) and $\mathrm{Cd}(\mathrm{II})$ by three variable charge soils from southern China. Environ Sci Pollut Res 20(12):8491-8501

Xu RK, Xiao SC, Yuan JH, Zhao AZ (2011) Adsorption of methyl violet from aqueous solutions by the biochars derived from crop residues. Bioresour Technol 102(22): 10293-10298

Xueyong Z, Zhe Y, Huifen L, Xianzhi L, Jianchao H (2018) Effect of soil organic matter on adsorption and insecticidal activity of toxins bacillus thuringiensis. Pedosphere 28:341-349

Yang F, Lee X, Wang B (2015) Characterization of biochars produced from seven biomasses grown in three different climate zones. Chin J Geochem 34:592-600

Yao Y, Gao B, Zhang M, Inyang M, Zimmerman AR (2012) Effect of biochar amendment on sorption and leaching of nitrate, ammonium and phosphate in a sandy soil. Chemosphere 89:1467-1471
Yargicoglu EN, Sadasivam BY, Reddy KR, Spokas K (2015) Physical and chemical characterization of waste wood derived biochars. Waste Manage 36:256-268

Yenisoy-Karakaş S, Aygun A, Gunes M, Tahtasakal E (2004) Physical and chemical characteristics of polymer-based spherical activated carbon and its ability to adsorb organics. Carbon 42:477-484

Yu H, Zhang Z, Li Z, Chen D (2014) Characteristic of tar formation during cellulose, hemicellulose and lignin gasification. Fuel 118:25-256

Yuan J-H, Xu R-K, Zhang H (2011) The forms of alkalis in the biochar produced from crop residues at different temperatures. Bioresour Technol 102:3488-3497

Zama EF, Zhu Y-G, Reid BJ, Sun G-X (2017) The role of biochar properties in influencing the sorption and desorption of $\mathrm{Pb}(\mathrm{II}), \mathrm{Cd}(\mathrm{II})$ and $\mathrm{As}(\mathrm{III})$ in aqueous solution. J Clean Prod 148:127-136

Zhang J, Liu J, Liu R (2015) Effects of pyrolysis temperature and heating time on biochar obtained from the pyrolysis of straw and lignosulfonate. Bioresour Technol 176:288-291

Zhang Z, Zhu Z, Shen B, Liu L (2019) Insights into biochar and hydrochar production and applications: a review. Energy 171:581-589

Zhao S-X, Na T, Wang X-D (2017) Effect of temperature on the structural and physicochemical properties of biochar with apple tree branches as feedstock material. Energies 10:1293

Zheng W, Sharma BK, Rajagopalan N (2010) Using Biochar as a Soil Amendment for Sustainable Agriculture. Report in Illinois Sustainable Technology Center

Zhu X, Chen B, Zhu L, Xing B (2017) Effects and mechanisms of biochar-microbe interactions in soil improvement and pollution remediation: a review. Environ Pollut 227:98-115

Zielińska A, Oleszczuk P, Charmas B, Skubiszewska-Zięba J, Pasieczna-Patkowska S (2015) Effect of sewage sludges properties on the biochar characteristic. J Anal Appl Pyrol 112:201-213

Zimmerman AR (2010) Abiotic and microbial oxidation of laboratory-produced black carbon. Environ Sci Technol 44:1295-1301

Publisher's Note Springer Nature remains neutral with regard to jurisdictional claims in published maps and institutional affiliations. 